1976

\title{
Archaeological Investigations at Sites in the Upper Cibolo Creek Watershed, Central Texas
}

Thomas C. Kelly

Thomas R. Hester

Center for Archaeological Research

Follow this and additional works at: https://scholarworks.sfasu.edu/ita

Part of the American Material Culture Commons, Archaeological Anthropology Commons, Environmental Studies Commons, Other American Studies Commons, Other Arts and Humanities Commons, Other History of Art, Architecture, and Archaeology Commons, and the United States History Commons

Tell us how this article helped you.

This Article is brought to you for free and open access by the Center for Regional Heritage Research at SFA ScholarWorks. It has been accepted for inclusion in Index of Texas Archaeology: Open Access Gray Literature from the Lone Star State by an authorized editor of SFA ScholarWorks. For more information, please contact cdsscholarworks@sfasu.edu. 


\section{Archaeological Investigations at Sites in the Upper Cibolo Creek Watershed, Central Texas}

\section{Creative Commons License}

\section{(c) (1) (8)}

This work is licensed under a Creative Commons Attribution-NonCommercial 4.0 International License 


\section{Archaeological Investigations at Sites in the Upper Cíbolo Creek Watershed, Central Texas}

Thomas C. Kelly and Thomas R. Hester

Center for Archaeological Research The University of Texas at San Antonio Archaeological Survey Report, No. 17

1976 


\section{ARCHAEOLOGICAL INVESTIGATIONS AT SITES IN THE UPPER CIBOLO CREEK WATERSHED, CENTRAL TEXAS}

Thomas C. Ke11y and Thomas R. Hester

Center for Archaeological Research The University of Texas at San Antonio Archaeological Survey Report, No. 17

1976 


\section{TABLE OF CONTENTS}

\section{Page}

List of Figures

i i

Introduction

1

Survey Procedures

1

Survey Results 1

Conclusions and Recommendations 29

$\begin{array}{ll}\text { Bibliography } & 33\end{array}$ 


\section{LIST OF FIGURES}

Figures

Page

1. Locations of Archaeological Sites in the Area of Floodwater Retarding Structure No. 1, Upper Cibolo Creek Watershed.

2. Artifacts from the Upper Cibolo Creek Watershed. 5

3. Site 41 KE 49. View of Site Area. 9

4. Site 41 KE 49. Contour Map. 12

5. Projectile Points from 41 KE 49. 13

6. Projectile Points from $41 \mathrm{KE} 49$. 15

7. Projectile Points from 41 KE 49. 17

8. Bifacial and Unifacial Artifacts from 47 KE 49.

9. Projectile Points from 41 KE 49. 21

10. Artifacts from $41 \mathrm{KE} 49$. 22

11. Flake Debris at 41 KE 49 . 24

Table

1. Postulated Future Inundations, Site 41 KE 49. 32 


\section{INTRODUCTION}

In August, 1976, the Center for Archaeological Research, The University of Texas at San Antonio, conducted an intensive archaeological survey of the proposed Floodwater Retarding Structure No. 1 area, in the Upper Cibolo Creek Watershed, Kenda11 County, Texas. The work was carried out under the terms of a contract (135-TX-SCS-76) with the U.S.D.A. Soil Conservation Service. An initial survey of this area had been conducted in February, 1975; two historic and 17 prehistoric archaeological sites were documented at that time (Bass and Hester 1975).

The intensive survey had three major objectives: (1) to conduct additional reconnaissance, thus insuring that all possible sites had been identified in the project area; (2) to better evaluate certain of the previously identified archaeological resources in terms of their possible nomination to the National Register of Historic Places; and (3) to carry out intensive survey and test excavations at a major prehistoric site, $41 \mathrm{KE}$ 49, and to ascertain if it was worthy of nomination to the National Register of Historic Places.

\section{SURVEY PROCEDURES}

The entire project area was covered on foot with the exception of an area of 200 by $600 \mathrm{~m}$ south of the creek on the property of C. A. Bergman. This area is dense cedar thicket and is, for all practical purposes, impenetrable. However, Mr. Bergman, who has 1 ived on the property all his life and who is an artifact collector, stated that he had never noted any archaeological materials in that area.

Mr. Harold Coffee, SCS District Conservationist at Boerne, Texas, secured entry permission from local landowners and he also provided a large scale plat map of the proposed structure.

A11 sites (those previously located in February, 1975, and a 71 new sites) were plotted on the USGS Ranger Creek (7.5') map using the Universal Transverse Mercator (UTM) metric grid. Where possible, the approximate centers of the sites were more precisely located using the plat map, a Silva compass, and reciprocal bearings on known landmarks. It is believed that all of the sites are plotted within a 10-meter margin or error. Shovel tests were made in all sites and standard excavation techniques were used in the three sites that were test excavated.

\section{SURVEY RESULTS}

During the intensive survey, many of the previously documented sites (Bass and Hester 1975) were revisited. Additional site survey led to the discovery of six prehistoric sites (41 KE 60-65). Locations of all known sites in the project area are shown in Fig. 1. The precise UTM grid coordinates are on file at the Center for Archaeological Research. 
This page has been

redacted because it

contains restricted

information. 
A summary of findings at the previously documented sites and descriptions of the newly-recorded ones is provided in this section.

In the site descriptions that follow, measurements have been recorded in the metric system. An exception is the elevation (above mean sea leve1) for each particular site. All elevation readings were obtained by consulting the USGS Ranger Creek map and the plat map made available by the SCS. On these maps, all elevations are indicated in feet. Since we believe that the agencies utilizing this report will find the English system most useful for planning purposes, we have made no attempt to convert the recorded elevations to their metric equivalents.

Artifacts collected during the course of the intensive survey have been processed and are stored at the laboratory of the Center for Archaeological Research. Other data on file at the Center are the site survey forms, photographs, field notes, and maps resulting from the field investigations. Duplicates of the site survey forms are also on file at the Texas Archeological Research Laboratory, The University of Texas at Austin.

The Sites

\section{$41 K E 25$}

The site is on a bluff $90 \mathrm{~m}$ east of where the access road from the Ranger Creek road drops sharply to the concrete low water crossing of Cibolo Creek. It 1 ies between the $1500^{\prime}$ and $1520^{\prime}$ contour intervals in grass and scrub brush with a few cedar and live oak trees. Only a few flakes were visible and shovel tests into the thin clay soil produced negative results; no burned rock or finished artifacts were observed.

\section{$41 K E 26$}

This site is located in a grass field adjacent to a small grove of 1 ive oak and cedar on a high terrace just above, and on the south side of, Cibolo Creek. It is $160 \mathrm{~m}$ east of the fence dividing the Fuqua and Bergman properties, and 1 ies between the $1500^{\prime}$ and $1520^{\prime}$ contours. A careful search revealed only a few flakes and broken chert cobbles. No burned rock was found. Widely spaced shovel tests indicated that all cultural material lies within the top $15 \mathrm{~cm}$.

\section{$41 K E 27$}

The site is on the proposed dam centerline on a bluff north of the creek and east of the paved low water crossing. It is situated in a grove of live oaks, cedar, and grass, between the $1480^{\prime}$ and $1500^{\prime}$ contour intervals. The site is very small; only a few flakes could be found and shovel tests had negative results.

\section{KE 29}

This site is exposed by an eroding farm road that runs along the top of 
the bluff in the centerline of the northwest leg of the dam. The edge of the bluff is on the 1500' contour and a recent bench mark (No. 5) is clearly identified on a large oak tree that is on the south edge of the site.

The soil is red clay and there is a moderate outcrop of chert cobbles eroding from the surface. The site is small, approximately $12 \mathrm{~m}$ in diameter, and is split by the road. Large oak trees 7 ine the edge of the bluff on the south edge of the site, and Johnson grass and weeds occupy the formerly cultivated field to the north toward Upper Cibolo Road.

The total artifact inventory consists of a Pedernales projectile point (Fig. 2,h), three broken biface preforms, a unifacially worked pebble and several utilized flakes (including a trimmed cortex flake). Shovel tests revealed the site deposit to be thin.

\section{$41 \mathrm{KE} 30$ and $41 \mathrm{KE} 31$}

Both sites were originally reported in Bass and Hester (1975). Sma11 samples of 1 ithics were obtained from the sites at the time of the original survey. During intensive survey activities, a stemmed dart point was collected from 41 KE 31 (Fig. 2,i). Both sites 7 ie just above the 1520' elevation.

41 KE 32

The site is in the Gilliat east pasture $570 \mathrm{~m}$ from the Gilliat house on a magnetic bearing of $153^{\circ}$. It is in the edge of a field just north of Cibolo Creek, at a point where the creek completes an oxbow bend to the east; the elevation in this area is approximately $1520^{\prime}$. A thin scatter of 7 ithic materials parallels the creek bend in a band approximately $10 \mathrm{~m}$ wide and $120 \mathrm{~m}$ in length. Shovel tests indicate a thin layer of brownish clay topsoil over buff-colored clay beginning at $20 \mathrm{~cm}$. No flakes were found below $15 \mathrm{~cm}$, the approximate depth of plowing. The site has been completely disturbed by repeated plowing.

\section{KE 33}

The site lies in the Gilliat east pasture $470 \mathrm{~m}$ from the Gilliat house on a magnetic bearing of $153^{\circ}$. The site is exposed by a gully that begins at the southwest edge of a small grove of trees in the field and runs southwest $145 \mathrm{~m}$ to empty into the east leg of the Cibolo creek oxbow. This site is situated between 1520'-1530' in elevation. The gully cuts through brown clayey topsoil and into the underlying buff calcareous clay (a basal limestone is exposed at the extreme southwest end). An especially heavy 1 ithic concentration, roughly circular in shape and $78 \mathrm{~m}$ in diameter, is found $20 \mathrm{~m}$ east of cibolo creek. The field is in Johnson grass but the surface in the gully area has been exposed by erosion. 
Figure 2. Artifacts from the Upper Cibolo Creek watershed.

$a-g, 41 K E 33$

h, 41 KE 29

$i, \quad 47 \mathrm{KE} 31$

$j, \quad 41 \mathrm{KE} 52$

$k, \quad 41 \mathrm{KE} 61$

1-p, 41 KE 63 ( $p$ is a potsherd);

$1, m$, and $p$ are from the Bergman collection; $n$ is from Unit $A$, level 3 , and 0 is a surface find. 

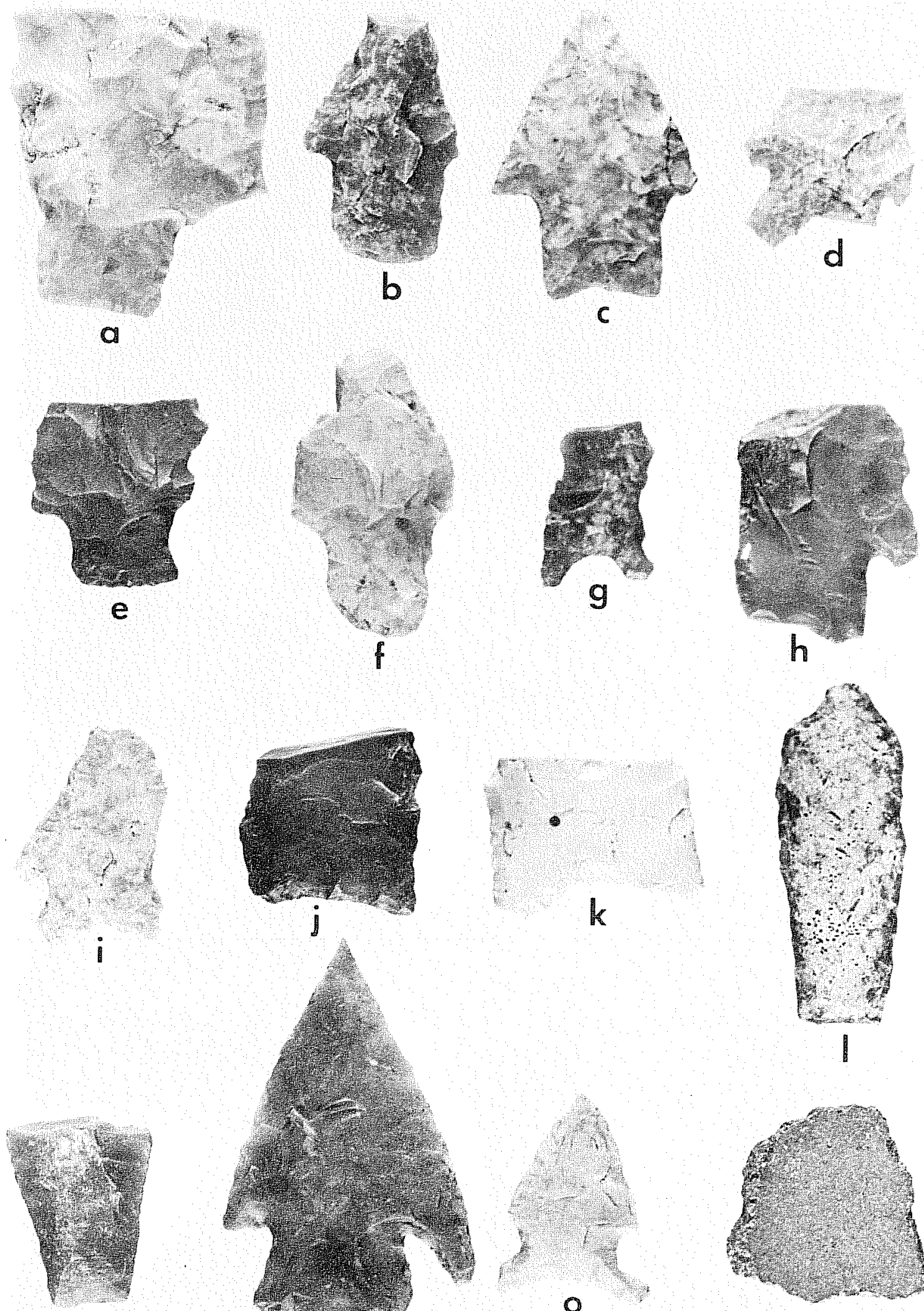

m
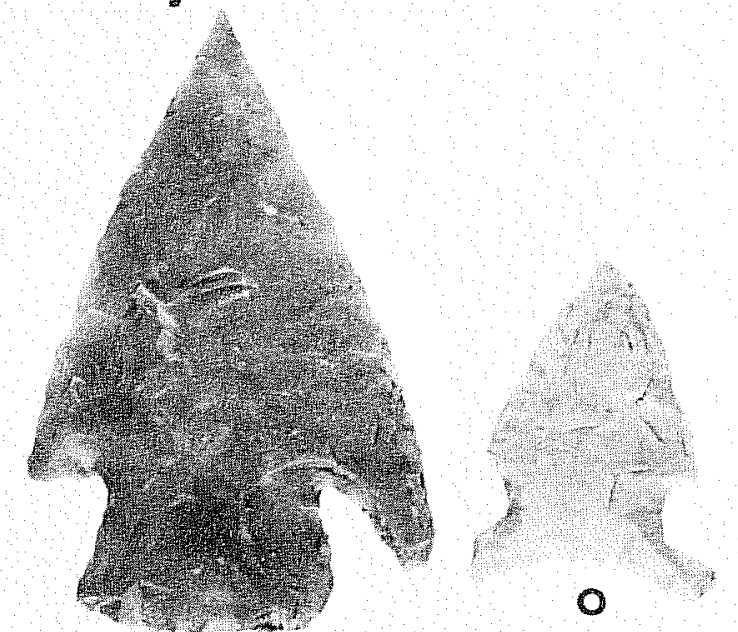

$$
\mathrm{cm}\left|\begin{array}{lll|l|l|l|}
1 & 1 & n & 1 & 1 & 1 \\
3 & 4 & 5
\end{array}\right|
$$

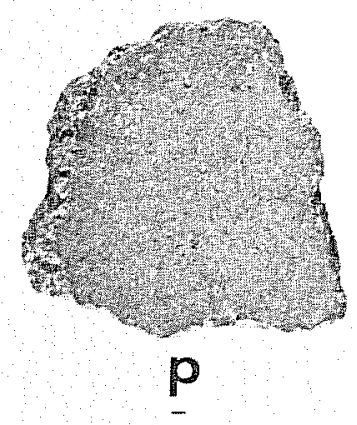


Surface artifacts collected at the time of the present intensive survey include two thin biface preforms, three thick biface preforms, one preform with a rectangular stem, one miscellaneous biface (perhaps a knife or scraper), a scraper made on a flake, one Pedernales dart point, one Montell (?) dart point, one Gower dart point, one Nolan dart point, and eight dart point fragments (see Fig. 2,a-g). Another 1ithic sample from the site is reported by Bass and Hester (1975).

Limited shovel tests failed to reveal any buried artifacts. All eroded artifacts appear to lie on top of the buff calcareous clay and none were found within this formation. The buff calcareous clay has proved to be devoid of artifacts throughout the survey area wherever shovel tests or test pits penetrated into it. It apparentiy predates a 17 the Pre-Archaic and Archaic artifacts recovered during the survey. Since dart points from several periods (Pre-Archaic, Early Archaic, Middle

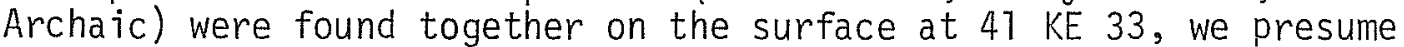
that the site has been eroded with all artifacts deposited on a common surface. No burned rock or hearths were observed.

$41 K E 34$

The site is in the Gilliat east pasture $370 \mathrm{~m}$ on a magnetic bearing of $159^{\circ}$ from Gilliat house. It 7 ies parallel to the creek for $100 \mathrm{~m}$ north of $41 \mathrm{KE} 33$ and at a similar elevation. Most cultural debris is exposed in an area five $m$ wide along a pasture trail. Only a few flakes were observed and nothing was found in shovel tests.

\section{$41 K E 35$}

This site lies $250 \mathrm{~m}$ south of Upper Cibolo Road, $250 \mathrm{~m}$ west of the Fuqua/Gilliat boundary fence in the Gilliat east pasture. It is between the $1520^{\prime}$ and $1450^{\prime}$ contour levels. Lithic material is exposed along a gully that runs from northeast to southwest across the field. The site covers $60 \mathrm{~m}$ along the gully and averages about $20 \mathrm{~m}$ in width. The soil is red clay with an outcrop of chert cobbles of rather poor knapping quality. The gully cuts through the red clay to an underlying buff calcareous clay at the southern end of the site at the edge of a heavily wooded area. The survey team here found a Martindale (?) dart point exposed on the buff clay. Broken cobbles and knapping debitage were al so observed.

\section{KE 36}

The site is $230 \mathrm{~m}$ south of the Upper Cibolo Creek Road, $50 \mathrm{~m}$ west of the fence dividing the Gilliat and Fuqua properties and $50 \mathrm{~m}$ north of the riparian zone that parallels Cibolo Creek on its north side. Elevation in this area is approximately 1530'. The site is oval-shaped with the long axis being east-west and with dimensions of about 60 by $20 \mathrm{~m}$. The soil is a red clay and contains chert nodules, many of which have been broken. Only knapping debris was found and shovel tests indicate the absence of buried deposits. 


\section{$41 K E 37$}

The site is a burial plot located on the west side of a grove of 1 ive oak trees $250 \mathrm{~m}$ (on a magnetic bearing of $260^{\circ}$ ) from a stone house that Ties at the northwest turn point of the dam centerline. The elevation is given on the plat map of the area as 1493.2'. There are no grave markers and the area is fenced with barbed wire and has a small ornamental gate. It is three by five $m$ in area and, according to $C$. $A$. Bergman, members of the Agold family are buried there. The last interment was made about 1912. Hilda Agold of Boerne, Texas, can be contacted for further details.

\section{KE 43}

The site is on the bluff (elevation, 1500') at the northwest turning point of the dam centerline and consists of the ruins of a stone house. The earlier survey team collected a Nolan dart point, a stemmed dart point, cortex flakes and an exhausted core as well as miscellaneous historic material. Four test pits in and alongside the house failed to reveal any additional archaeological material. The earth within the foundations was fill surrounding cedar floor supports and either the chert found was in the fill, or there was an artifact collector 1 iving in the house at some time. The house was measured and the floor plan was drawn. Electric connections, a gas line, and a flush toilet as well as the remains of a form-poured standing wall indicate no great age or historical value to the house. A stone house of the same type of construction is still standing and in good shape just $100 \mathrm{~m}$ north.

\section{$41 K E 48$}

This site is located in the south edge of the Gilliat west pasture immediately north of the Gilliat Road. Site elevation is about 1540'. A lithic scatter about $20 \mathrm{~m}$ wide extends for $200 \mathrm{~m}$, paralleling the creek and road. Artifact collectors have scoured this site for many years and have removed all diagnostic artifacts. However, the survey team did find a thin pointed biface with a rounded scraping end, a fist-sized bifacial artifact with an extremely blunted and step-fractured edge (chopper?), and a crude unfinished biface. Plow damage to the site has been extensive, as shovel tests revealed the topsoil over the buff clay subsoil was thinner than the depth of the plow zone.

\section{KE 49}

Following the recommendations of Bass and Hester (1975), one of the major goals of the intensive survey was to obtain a better assessment of site $41 \mathrm{KE} \mathrm{49}$. The tasks performed by the intensive survey team included additional surface collecting, mapping (see Fig. 4), and test excavation. The latter was necessary in order to determine the extent and character of the site. 
Figure 3. Site $41 \mathrm{KE}$ 49. a, View of site area looking east-southeast; $b$, in situ materials in Unit $G$, level 2 $(15-30 \mathrm{~cm})$. Note the two dart points in the foreground (see Fig. 7,b; Fig. 5,j). 


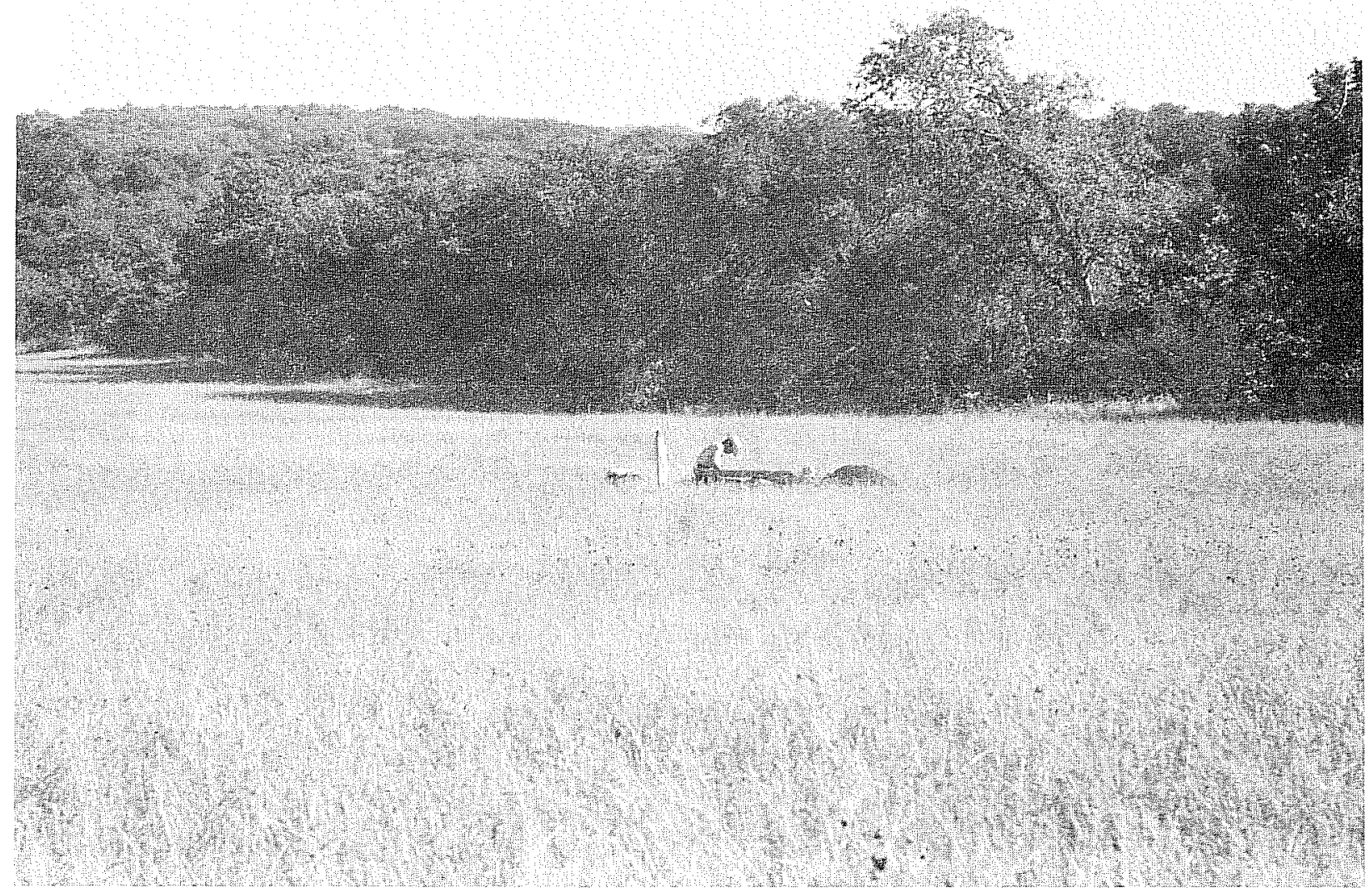

a

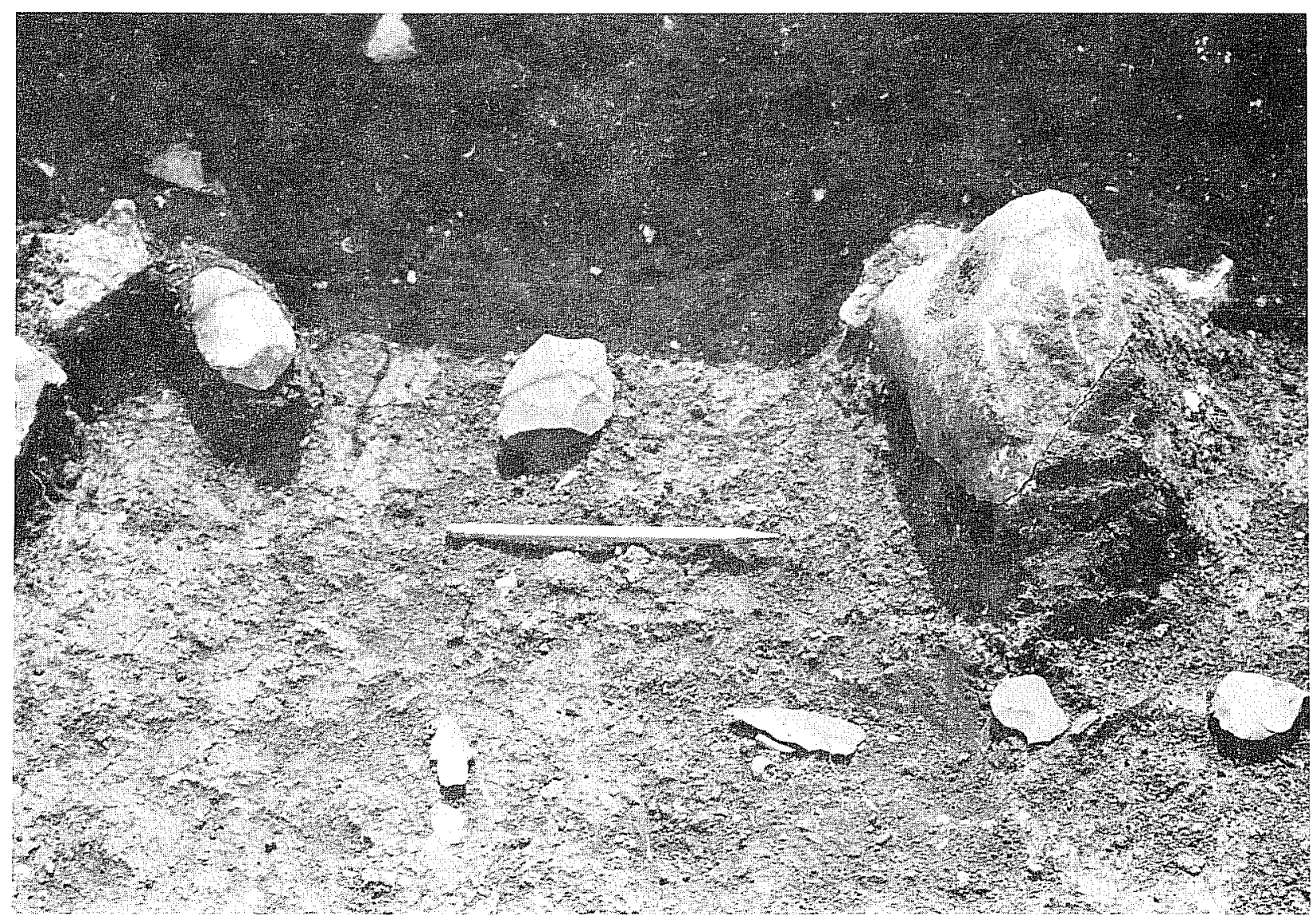


The site is located in the southeast end of a field within a large bend of Cibolo Creek (Fig. 1). It lies $500 \mathrm{~m}$, on a magnetic bearing of $174^{\circ}$, from the Gilliat home. The north fence line of the C. A. Bergman property cuts across the south end of the site and was used as the datum Tine for the "Survey Map of the Upper Cibolo Creek Reservoir, Easement and Property Line Survey" (on file at the SCS office, Boerne). Thus, the location of $41 \mathrm{KE} 49$ can be tied to a detailed survey if necessary.

The field in which the site is situated is $360 \mathrm{~m}$ long (northwest to southwest) and $240 \mathrm{~m}$ wide (east-west). It is contained within the 1520'$1540^{\prime}$ contour intervals, rising from north to south and from east to west. The terrain rises to an elevation of $1710^{\prime}$ within $600 \mathrm{~m}$ to the south, and the topography is such that much of the drainage from the uplands is deposited in the field. Soils at the site are typical of the TarrantBrackett-Speck series. The field was fallow at the time of the investigations, and contained scattered Johnson grass and an abundant crop of burrs. The banks of Cibolo Creek and the uplands above the field have a lush growth of post oak, live oak, cedar, hackberry, persimmon, sumac, black walnut and a few elm and hickory trees. Fauna observed during the field work included eight wild turkeys seen in the field one morning and numerous white tail and Axis deer (the latter is an imported species) which were seen daily. Other fauna noted by the field crew included turkey vulture, armadi110, raccoon and squirrel.

The initial survey of 41 KE 49 (Bass and Hester 1975) noted the archaeological potential of this site. In a controlled surface collection made at that time, a number of artifacts were collected. These included Nolan and Tortugas dart points (Bass and Hester 1975:24). The Tortugas point has been re-examined by Hester, and he believes that it represents the Early Triangular form as found at the La Jita site in Uvalde County (Hester 1971:79), the Granberg II site in Bexar County (Hester and Kohnitz 1975), and at a number of other Early Archaic and/or Pre-Archaic localities in Texas (cf. Sollberger and Hester 1972).

The first phases of intensive survey at 41 KE 49 entailed a close scrutiny of the ground surface, and the excavation of several shovel tests and six one-meter squares, all done in an effort to locate concentrations of occupational debris. These investigations produced a series of artifacts, including such diagnostic dart points as Plainview, Bell, Nolan, Early Corner-Notched and Bulverde. In addition, the field team was able to inspect a surface collection made by deer hunters who lease the area, and it was found to contain similar specimens (see Figs. 9,10). After this first phase, it was decided that the findings warranted additional test excavations. Subsequently, 11 one-meter square test pits were placed in various parts of the site. Alphabetical designations were assigned in the sequence of unit excavation, and hence we have the somewhat irregular order in which these units are lettered in Fig. 4.

Excavation of the test pits was conducted according to standard archaeological procedure. Arbitrary excavation levels, usually of $15 \mathrm{~cm}$ thickness, were used for vertical control. All deposits were screened through 1/4" hardware cloth, with spot-screening through $1 / 8^{\prime \prime}$ mesh 


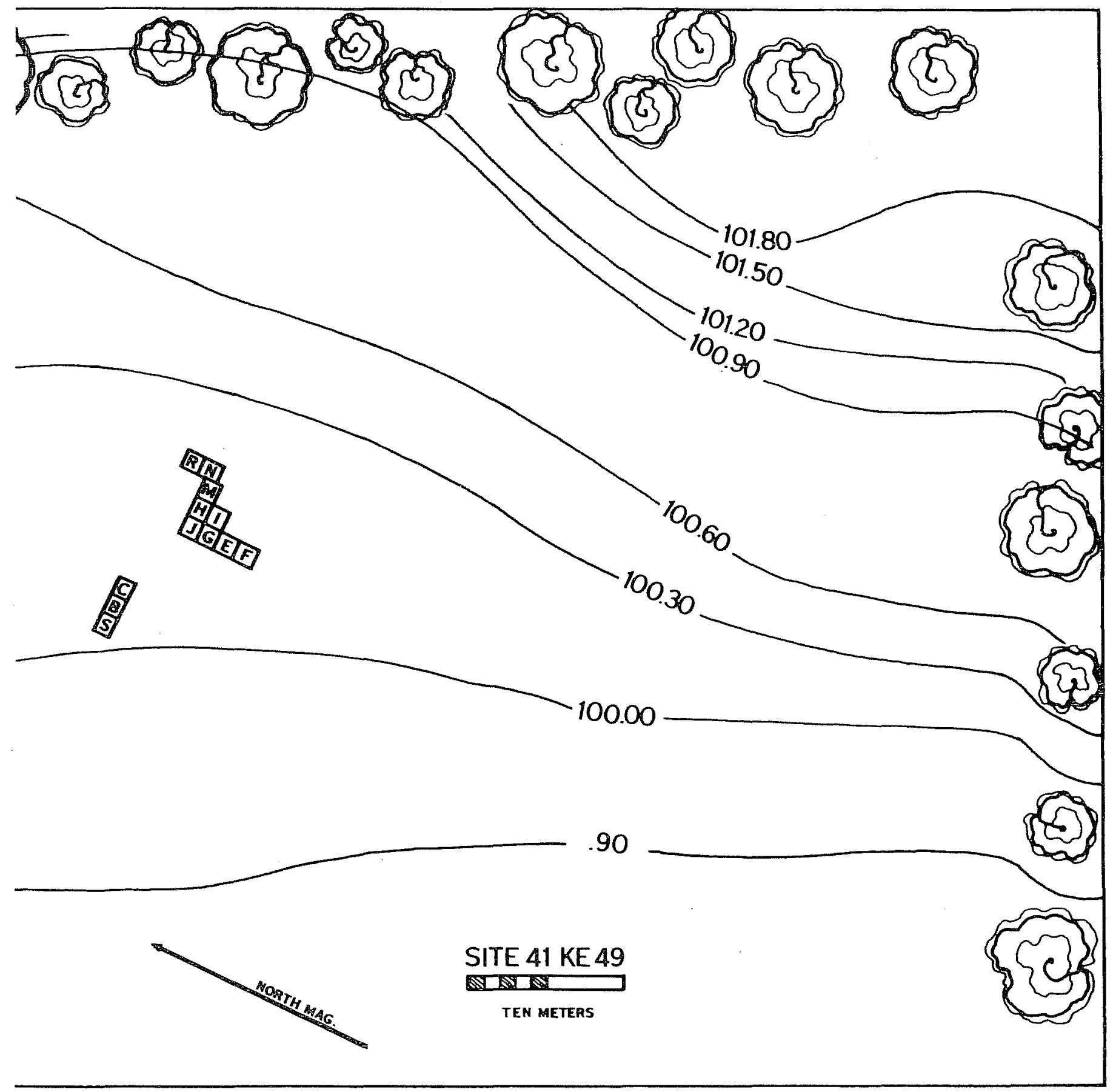

?location of major test pits at the site. 


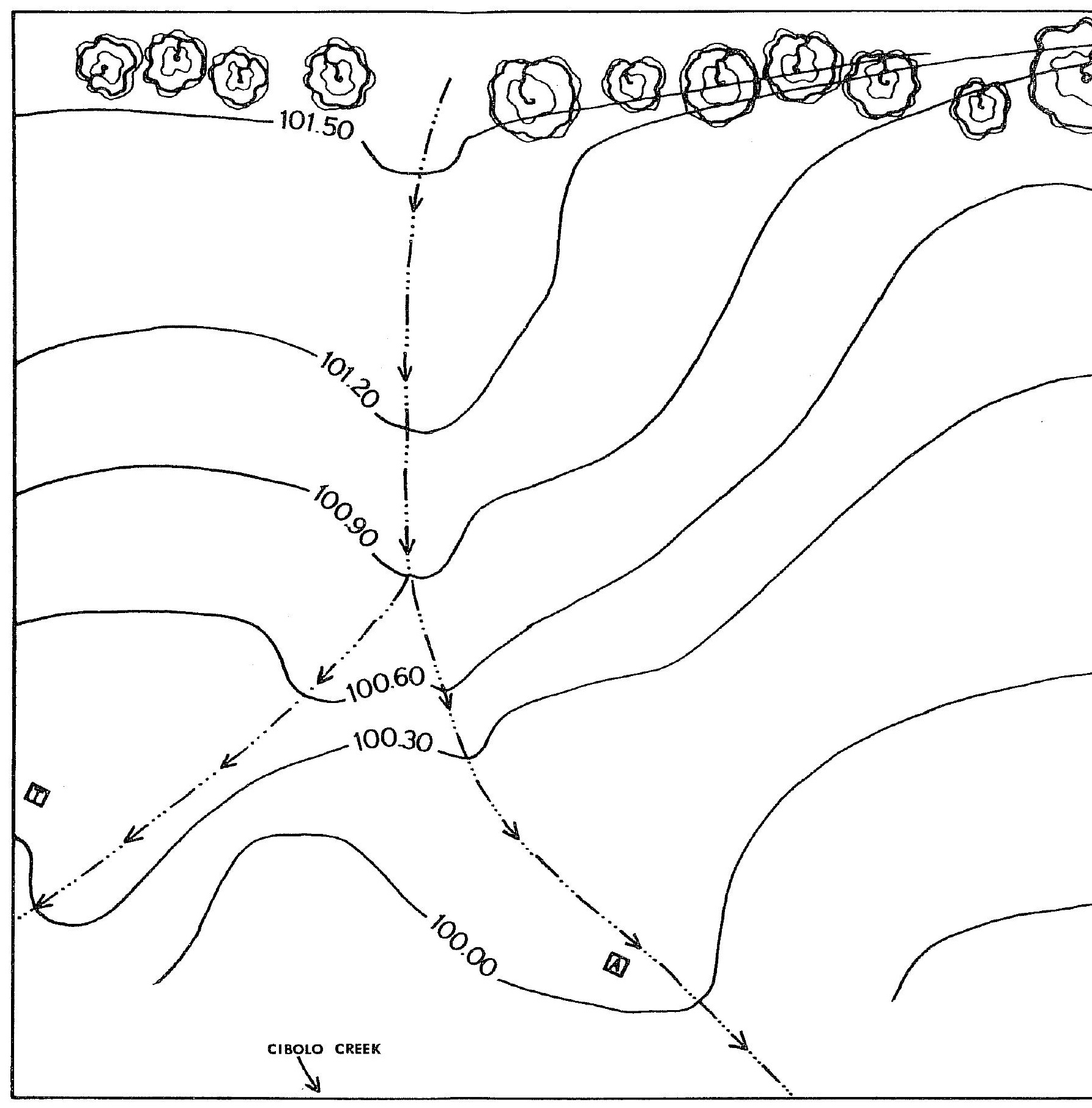

Figure 4. Site 41 KE 49. This contour map shows 
Figure 5. Projectile Points from 41 KE 49.

$$
\begin{aligned}
& \text { a, Surface } \\
& \text { b, Unit I, level } 3 \\
& \text { c, Surface } \\
& d \text {, Unit R, level } 2 \\
& \text { e, Unit M, level } 2 \\
& \text { f, Unit } F \text {, levels } 1-2 \\
& g \text {, Surface; arrow indicates burin } \\
& h \text {, Unit M, level } 2 \\
& i \text {, Surface } \\
& j \text {, Unit G, level } 2 \\
& \text { k, Unit E, level } 1 \\
& \text { I, Unit J, level } 2 \\
& m \text {, Surface } \\
& \text { n, Unit } E \text {, level } 2
\end{aligned}
$$




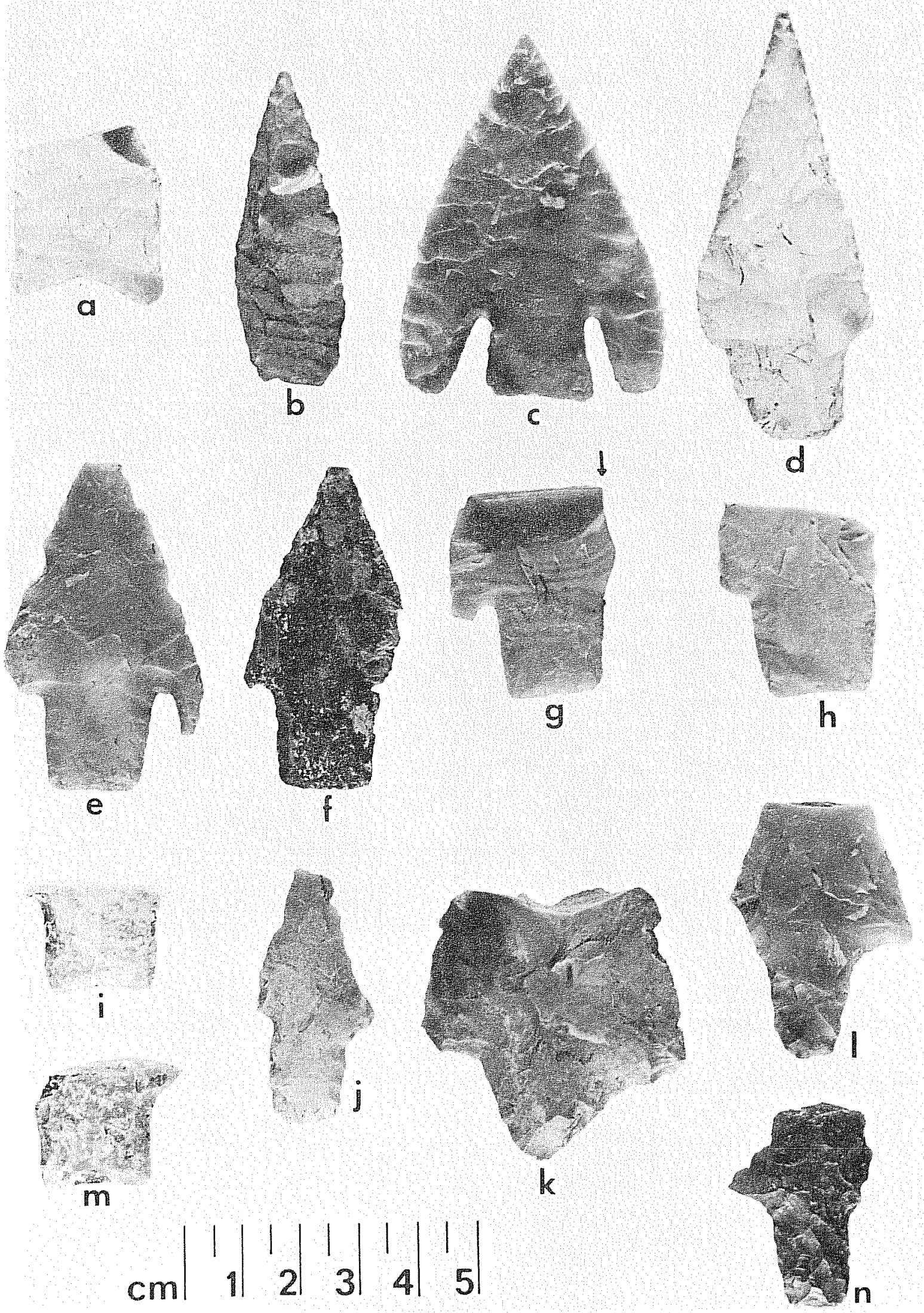


Figure 6. Projectile Points from 41 KE 49.

a, Unit $G$, level 2

b, Unit $H$, level 2

c, Unit $P$, level 2

d, Unit C, Tevel 3

e, Unit B, level 4

$f, g$, Unit $Q$, level 2

h, (Upper) Surface

i, Surface

$j$, Unit 0 , level 2

k, Unit $k$, lever 1

1, Unit B, Tevel 3 

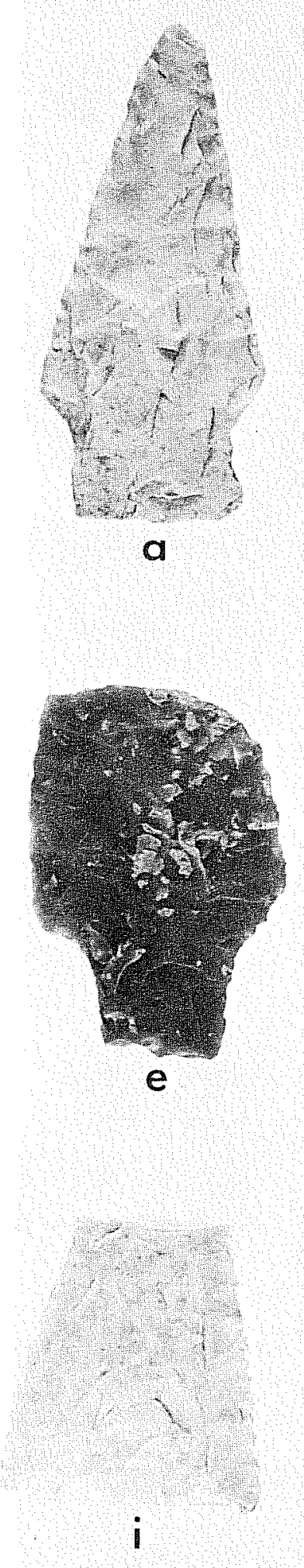

$\mathrm{cm} \mid$\begin{tabular}{ll|l|l|l|l|}
1 & 2 & $\mid$ & 1 & $\mid$ \\
& 1 & 3 & 4 & 5
\end{tabular}
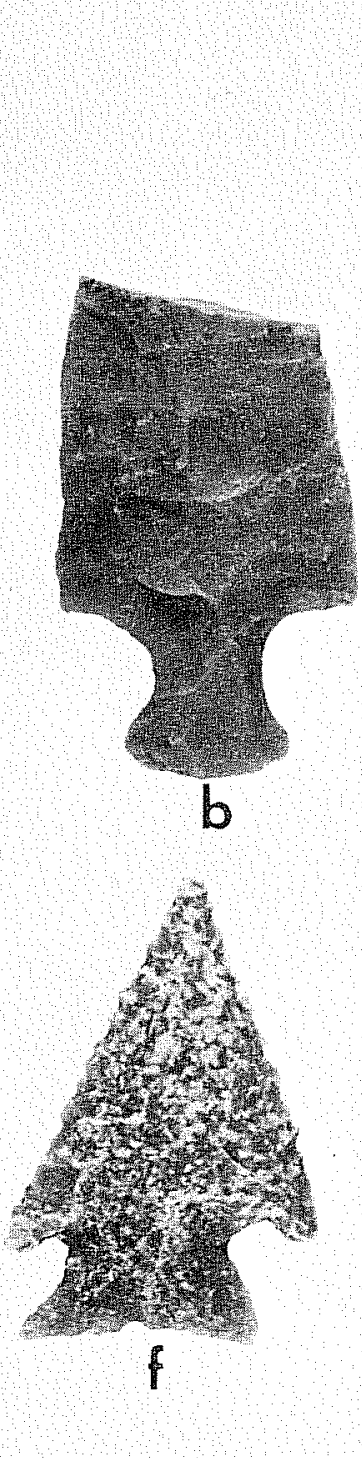
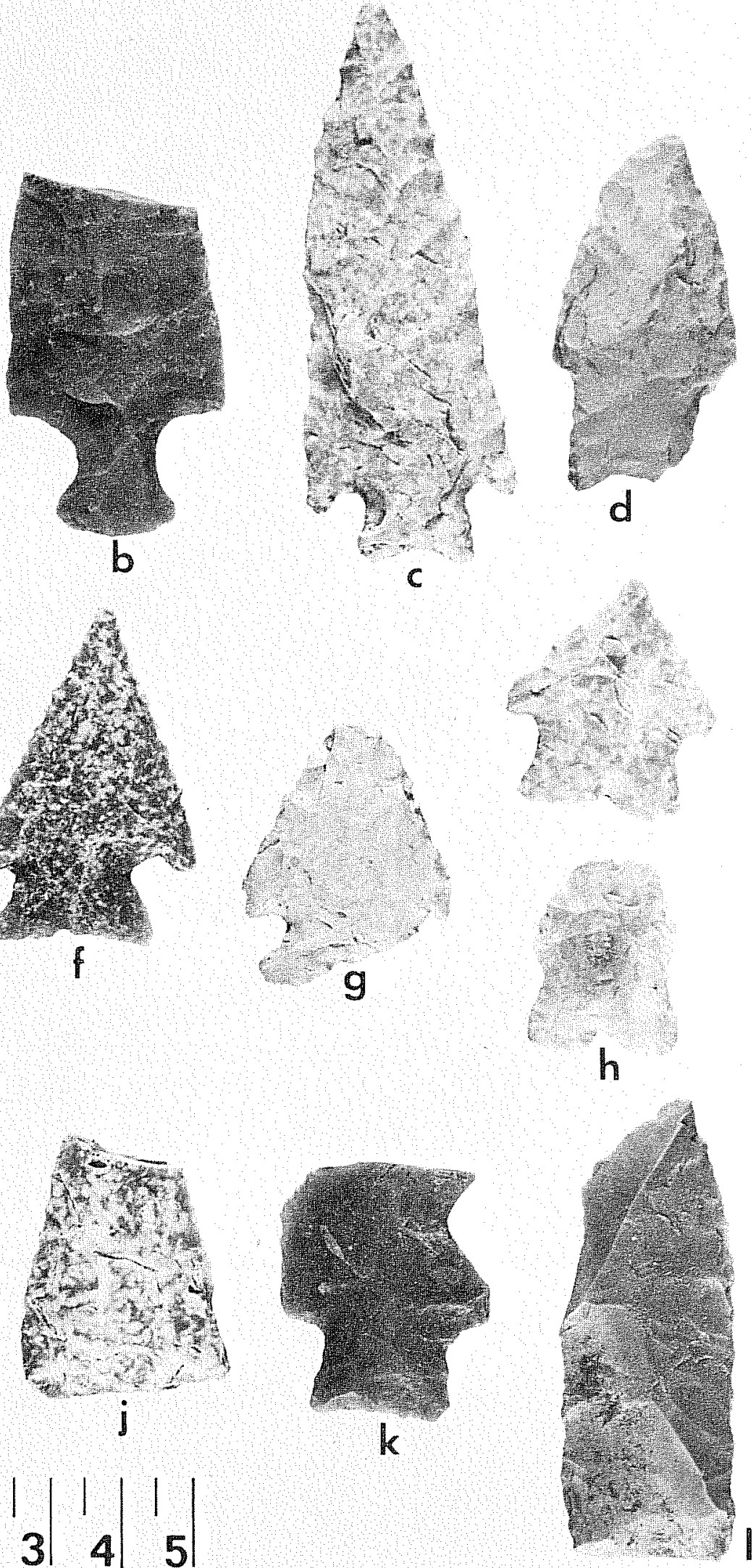
Figure 7. Projectile Points from 41 KE 49.
a, Unit $N$, level 2
$b$, Unit $G$, Tevel 2
C, Unit E, Tevel 2
d, Unit J, Tevel 2
e, Unit F, Tevel 1
$f$, Unit $A$, Tevel 1
g, Unit R, Teve1 2
$h$, Surface
$i$, Unit S, Teve 2
$j$, Surface
$k$, Unit $E$, level 2
1, Unit $N$, Teve 12
$\mathrm{m}$, Unit $\mathrm{S}$, lever 1
$n$, Unit $M$, Tevel 2 

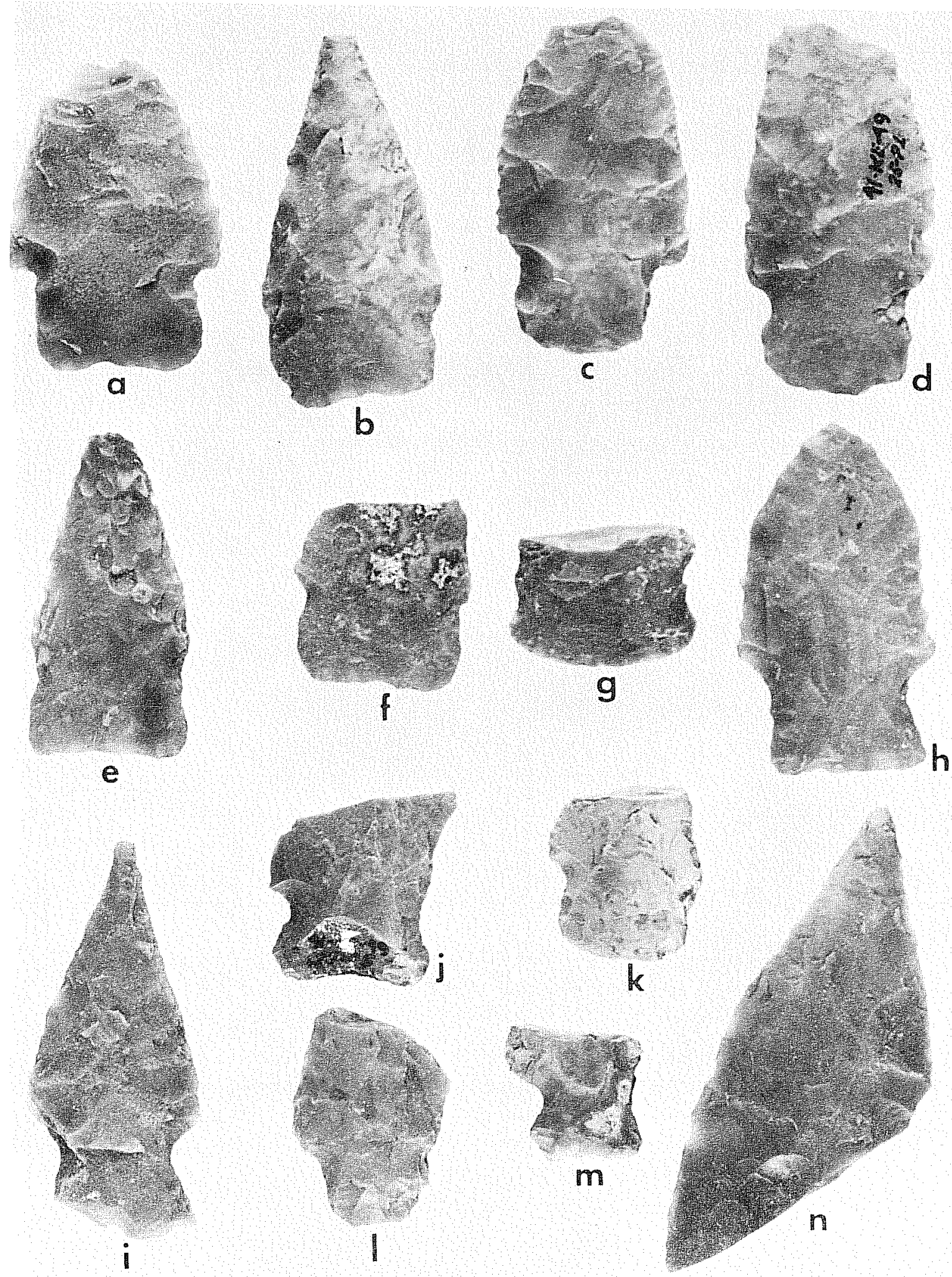

m

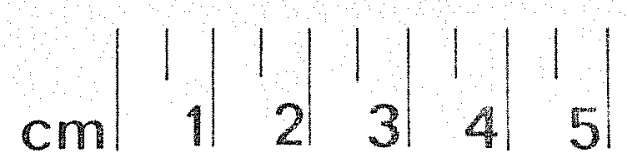


Figure 8. Bifacial and Unifacial Artifacts from 41 KE 49.

a, Bifacial preform, Unit 4, level 2

b, Uniface, Unit S, level 1

$c-f$, Unifaces;

$c$, Unit $U$, level 2

d, Unit R, level 2

e, Unit $K$, level 1

$f$, Unit 0

$g, h$, Large crude biface (surface); both faces shown 

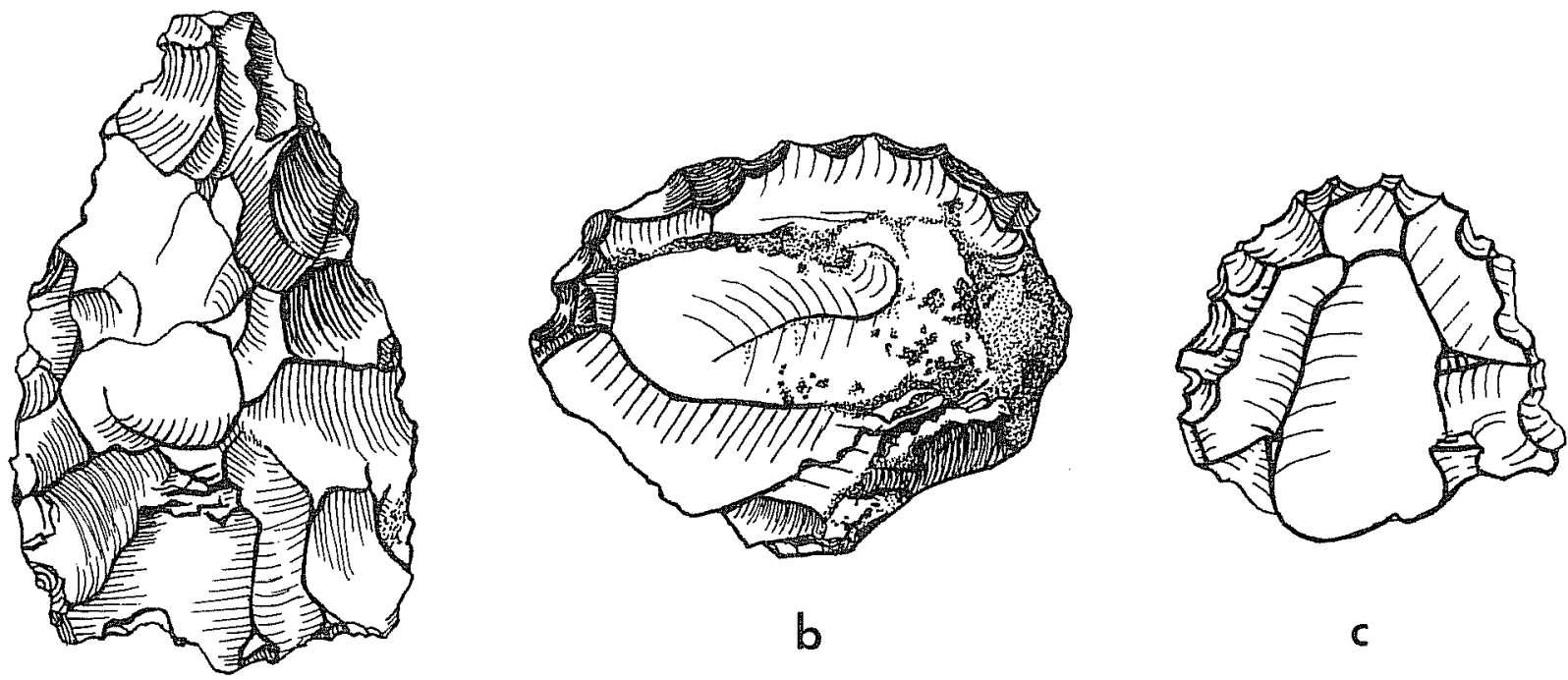

b

c
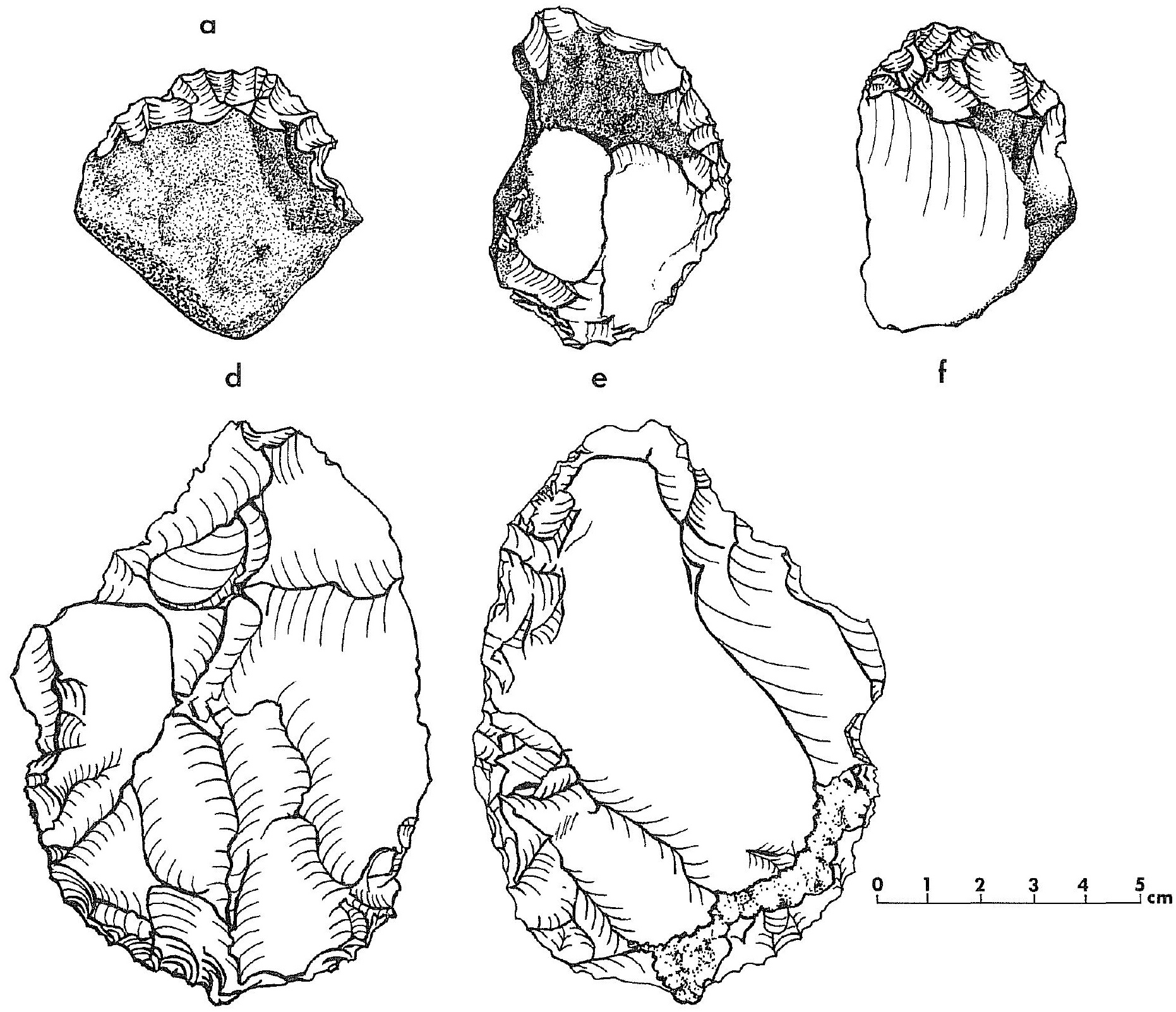

g

h 


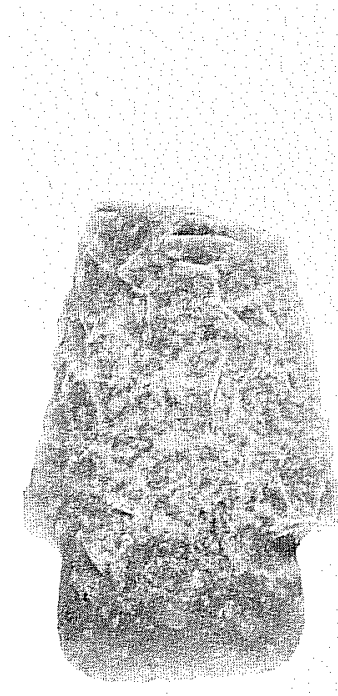

a
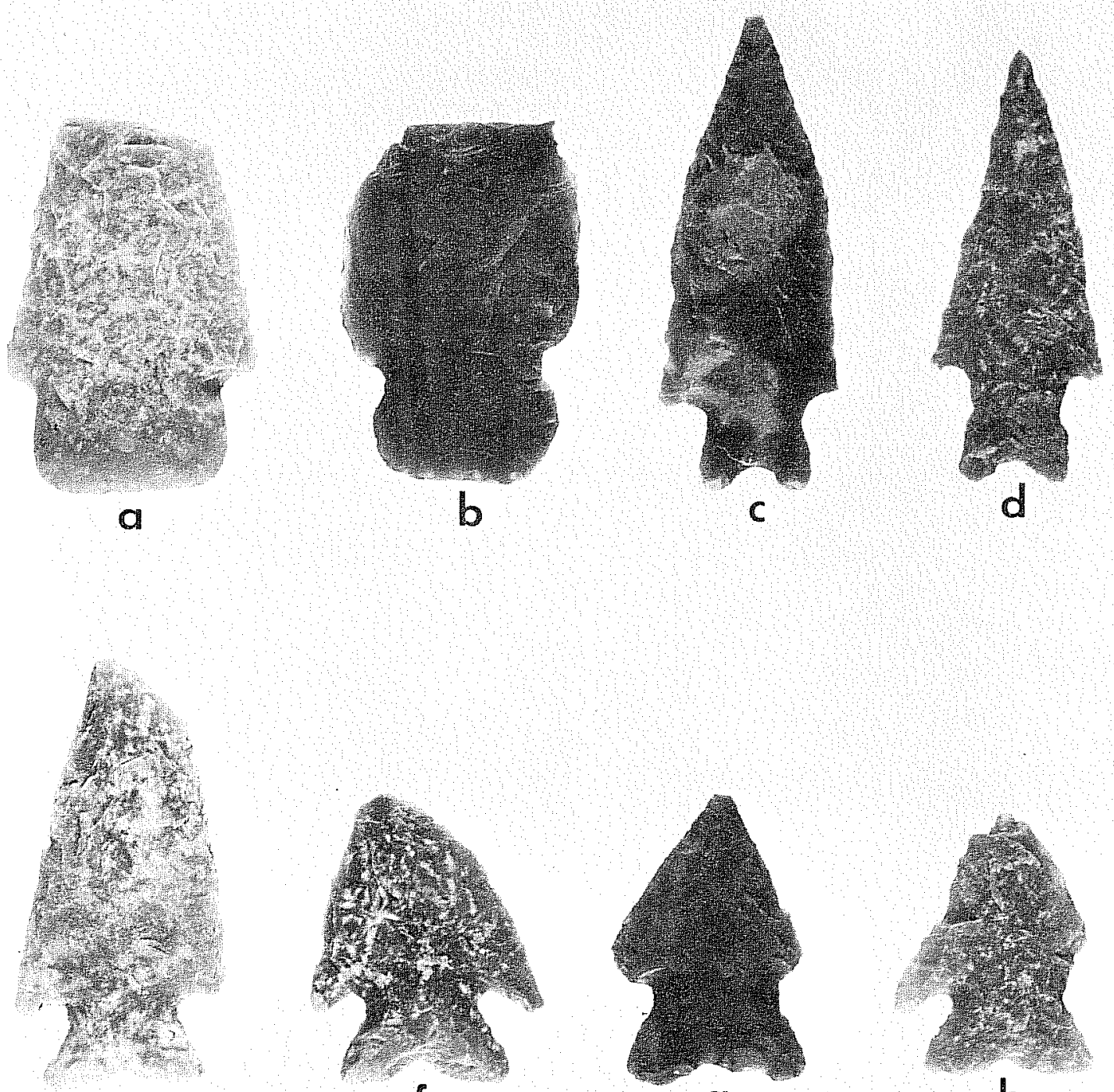

e
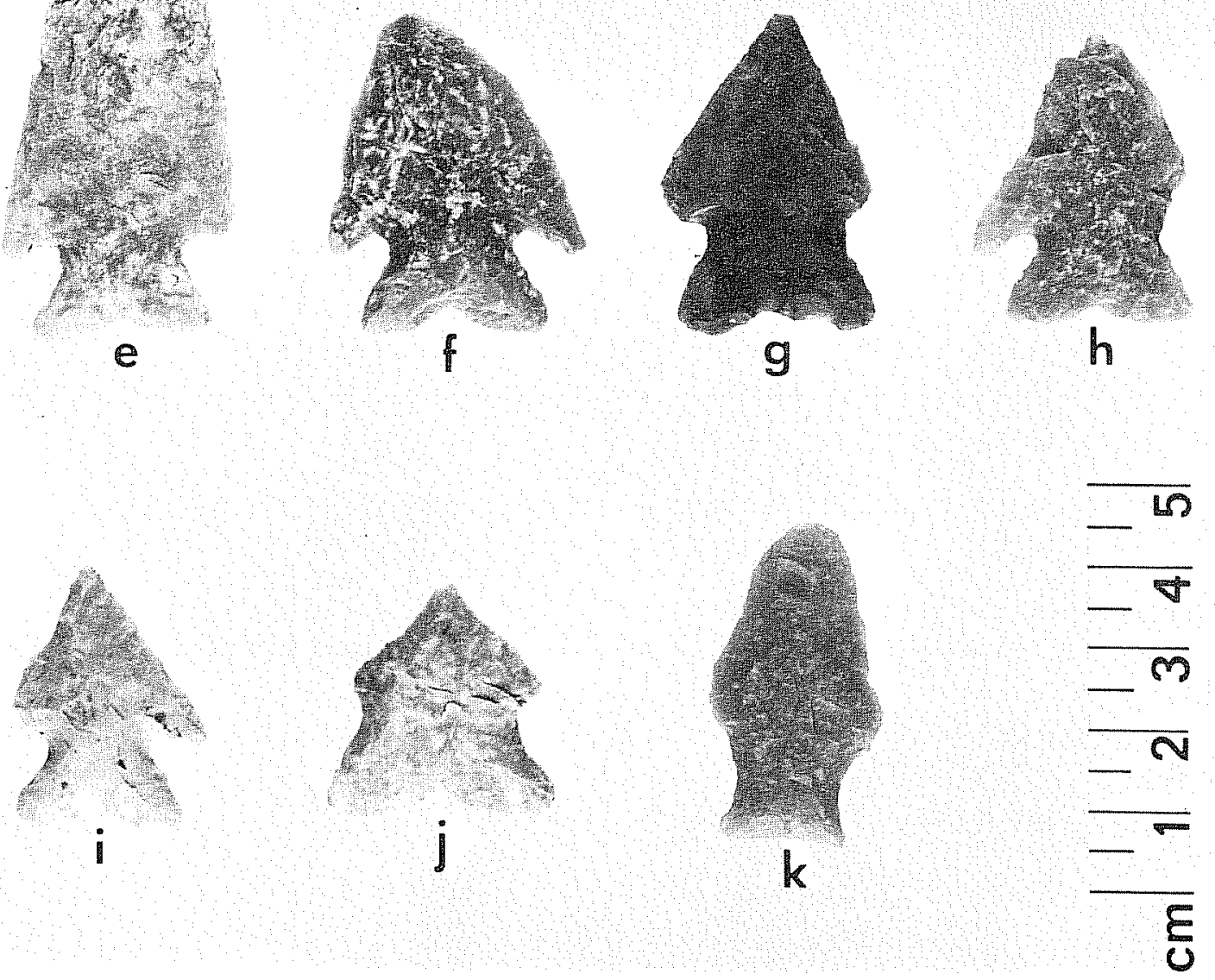

Figure 9. Projectile Points from 41 KE 49. Private surface collection. 


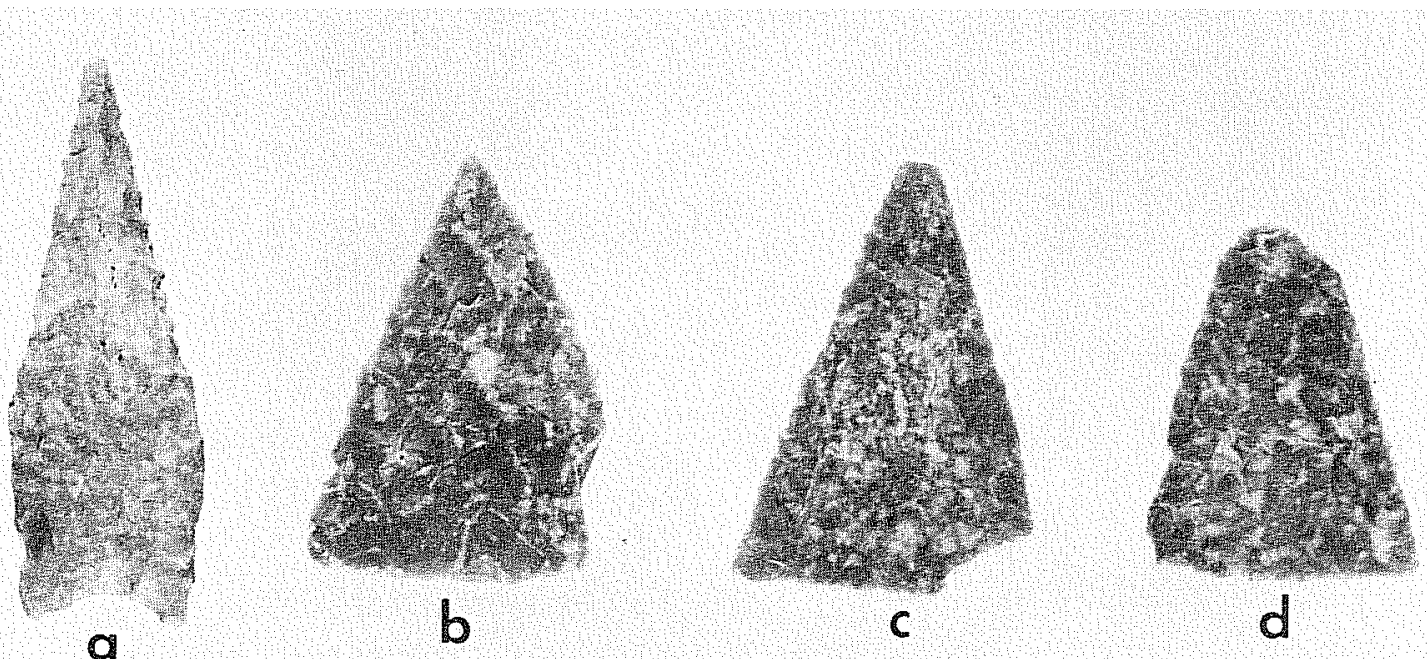

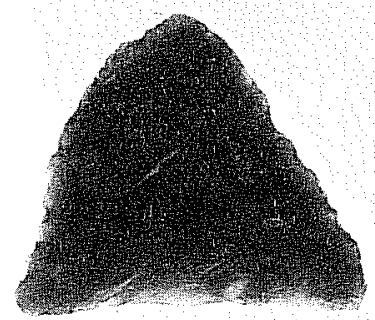

e
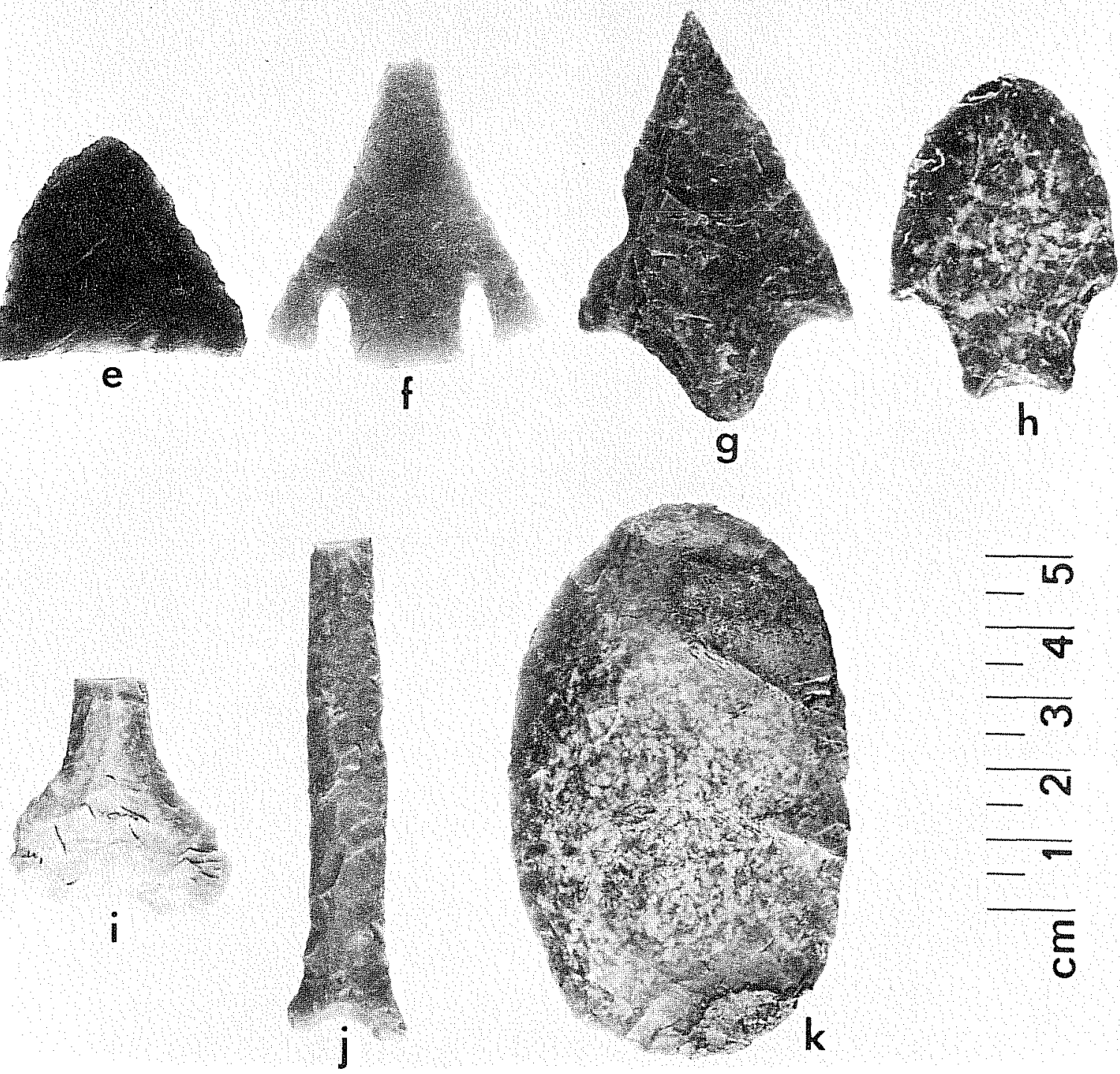

Figure 10. Artifacts from $41 \mathrm{KE}$ 49. Private surface collection. a-h, projectile points; $i, j$, perforators; $k$, unifacial tool (scraper). 
a second area of concentrated occupation. In general, the results of the excavations suggest to us that there were several occupation areas within the confines of the site. These appear to have been used with varying degrees of intensity and at different periods during the prehistoric past. Excavation on a larger scale would be needed to define and interpret these several, often overlapping, occupation Toci.

Briefly stated, 41 KE 49 appears to have been a favored camping locality for hunting and gathering groups at various times during the Pre-Archaic, Early Archaic and Middle Archaic eras. The occurrence of a Plainview point (in a surface context) suggests the possibility of even earlier occupations. With more extensive excavation, we believe that a great deal could be learned, from a horizontal perspective, about the use of the site area during the Archaic and in preceeding periods. Our test excavations indicate that hearth areas can be expected, and that carbonaceous materials suitable for chronometric dating will at times be present. We had hoped to recover a faunal sample from the site; however, animal bones were not present in the site deposits. In an effort to obtain faunal materials, however small or fragmentary, flotation technique was utilized. Unfortunately, this effort was aiso fruitless. Specimens recovered through flotation included chert flake fragments, fragments of snail shells and identifiable snails of the species Helicina orbiculata tropica and very tiny examples of what appear to be Helicodicus singleyanus and Amnicola integra. Helicodiscus singleyanus prefers a habitat beneath leaves in protected wooded areas, while Amnicola is found in the vicinity of permanent streams; the Helicina orbiculata tropica is a widespread, drought-resistant species found in fields and wooded areas (Allen and Cheatum 1961). The habitats of these snail species are, then, quite compatible with that present-day environment.

While we have not completed a full analys is of the excavated data, we are convinced that site 47 KE 49 offers great potential for further research. We are particularly impressed by the apparent abundance of occupational remains dating from Pre-Archaic and Early Archaic times. These are segments of the cultural sequence which rema in poorly known in south central Texas. We are also of the opinion that significant behavioral data could be recovered with open-area excavation techniques (cf. Hester, Heizer and Graham 1975:76-77). The site area appears to contain discrete occupational areas which might provide new information on the intra-settlement activities of the early hunting and gathering groups of the region. We will be making a recommendation for placement of the site on the National Register of Historic Places.

\section{KE 50}

This site is situated in the Gilliat oxbow field $150 \mathrm{~m}$ (on magnetic bearing of $296^{\circ}$ ) from the center of $41 \mathrm{KE} 49$. It lies on the $1540^{\prime}$ contour interval. A treel ine runs along the $1540^{\prime}$ contour 7 ine and the land rises steeply to the south and west. The site lies in the cultivated field immediately south of the treeline and consists of a thin 1ithic scatter in a roughly circular area of $15 \mathrm{~m}$ diameter. 
Shovel tests indicate that there are no buried deposits below the plow zone, and it is suggested that much of the material is derived from ups lope.

Bass and Hester (1975) reported a Tortugas point from the site, but re-examination indicates that it is another of the Early Triangular (Hester 1971) series like those recovered at $41 \mathrm{KE} \mathrm{49.} \mathrm{This} \mathrm{team} \mathrm{found} \mathrm{a}$ probably Early Corner-Notched point so this site is of considerable interest as both points apparently date from the Pre-Archaic era.

\section{KE 51}

The site Ties on the south bank of Cibolo Creek in C. A. Bergman's northeast pasture. It is $200 \mathrm{~m}$ upstream from the first bend of Cibolo Creek, west of the paved low water crossing and lake on the Fuqua property. It is situated on the $1480^{\prime}$ contour interval. The site consists of the remnants of a mid-19th century house abandoned about 1913 according to Mr. Bergman. Bass and Hester (1975) recommended no further action and the intensive survey team concurs with that recommendation.

\section{$41 K E 52$}

The site is $150 \mathrm{~m}$ southeast of the west end of the fence across the oxbow that separates the Bergman and Gilliat properties. It lies between the $1560^{\prime}$ and $1580^{\prime}$ contour intervals and is well above the reservoir limit of 1539'. An area approximately $30 \mathrm{~m}$ in diameter contained scattered Tithic materials and a Plainview basal fragment was found (Fig. 2,j). A very careful surface search failed to turn up additional diagnostic artifacts. Shovel tests indicate only a thin layer of soil (to a depth of $25 \mathrm{~cm}$ ) over solid limestone. The area is covered with grass, cedar, and 1 ive oak and does represent an undisturbed site as it has never been cultivated.

\section{KE 53}

The site is located just above the $1520^{\prime}$ contour interval on a steep bank south of Cibolo Creek. This area is in the northern part of a major bend in the creek; most of the Gilliat house is visible on magnetic bearing of $10^{\circ}$ at a distance of $300 \mathrm{~m}$. Lithic material was extremely light and widely dispersed.

\section{$41 K E 60$}

The site lies between Cibolo Creek and Gilliat road $260 \mathrm{~m}$ east of the stream crossing between the $1520^{\prime}$ and $1540^{\prime}$ contour intervals. It is clearly visible from the road and consists of a burned rock midden rising one $\mathrm{m}$ above the surrounding surface. It measures $20.5 \mathrm{~m}$ (east-west) by $13.5 \mathrm{~m}$ (north-south), and is oval in shape. There are great quantities of burned 7 imestone in angular chunks, with chert fragments, flakes and numerous snails scattered through the midden. Unfortunately, the midden has been completely vandalized by relic-collectors. Shovel tests to $1.5 \mathrm{~m}$, the level of the buff clay soil, revealed no artifacts other than 
chert flakes and broken nodules. There is a light lithic scatter across the road north into the field (the Gilliat west pasture) but no diagnostic artifacts were found, as this site has been scrutinized for years by relic-collectors from San Antonio and Boerne.

This site might still be of some archaeological value but would probably require considerable money and effort to study. It is the only burned rock midden located in the survey area and could possibly provide information on the Middle Archaic period which seems poorly represented in the survey.

\section{$41 K E \quad 61$}

This site is $80 \mathrm{~m}$ north of Gilliat road, $220 \mathrm{~m}$ east of its crossing of the Cibolo, in the Gilliat west pasture. It consists solely of lithic scatter in an area $10 \mathrm{~m}$ (north-south) by $30 \mathrm{~m}$ (east-west). The field is presently in Johnson grass, growing in a buff-colored calcareous clay soil. The site area is fairly flat and lies between the $1520^{\prime}$ and $1540^{\prime}$ contour leve1s. The area appears to be deflated, as shovel tests revealed no lithic material below the plow zone.

A Plainview point (Fig. 2,k) was found at this site, along with a weakly side-notched point, and a crude uniface made on a large flake.

\section{$41 K E 62$}

The site is $200 \mathrm{~m}$ north of the Gilliat Road crossing over Cibolo Creek, in the Gilliat west pasture. It is roughly circular, about $15 \mathrm{~m}$ in diameter, and consists solely of chert knapping debris. Crude, thick, bifaces, a crude denticulate scraper made on a heavy flake, large cortex flakes and a number of interior flakes constitute the sample from the site. The site is just above the $1540^{\prime}$ contour interval and lies outside the detention poot.

\section{$41 K E 63$}

The site is located on a ledge between the $1520^{\prime}$ and $1540^{\prime}$ contour intervals, on the south side of Cibolo Creek at the southeast end of the horseshoe bend (Fig. 1). The ledge or bench is $9 \mathrm{~m}$ wide at the site and narrows as the terrain climbs steeply to the top of the bluff $85 \mathrm{~m}$ east of the site at the $1560^{\prime}$ contour interval.

The nearly vertical face of the site, as exposed in the creek bank, was troweled and cut into a section at intervals for approximately $20 \mathrm{~m}$. A black zone from 10-40 $\mathrm{cm}$ in thickness was exposed at varying depths below the black humus topsoil. The zone was extremely rich in large snail shells, chert flakes, and most importantly, bone was found we 71 preserved, the only faunal evidence in the survey area. A typical section at $41 \mathrm{KE} 63$ can be described as follows (from the surface to a depth of $70 \mathrm{~cm}$ ): (1) $0-10 \mathrm{~cm}$; black, humus-stained soil, apparent7y of post-aboriginal origin; (2) $10-40 \mathrm{~cm}$; a black clayey soil containing burned rock, chert artifacts and debris, snails and bone fragments; (3) 40-70 cm, buff calcareous clay, with occupational debris only in 
the top $10 \mathrm{~cm}$.

The bench is lushly vegetated with Spanish oak, live oak, cedar, black walnut, elm, poison sumac, bunch grass and a wide variety of weeds. The site has a commanding view of a long straight stretch of cibolo Creek to the east and overlooks the Gilliat east pasture containing sites $41 \mathrm{KE} 32,33$ and 34 .

The site was "mined" for two years by relic-collectors. Mr. C. A. Bergman has obtained an interesting collection (Fig; 2,1,m,p) ranging from the Late Paleo-Indian period (Angostura points) to the Late Prehistoric (as represented by Perdiz arrow points and two sherds of grittempered pottery). He also found bison bones in the site deposits.

The survey team excavated two one-meter test pits, Unit $A$ to a depth of $80 \mathrm{~cm}$ and Unit $\mathrm{H}$, to $200 \mathrm{~cm}$, the last $100 \mathrm{~cm}$ of which was in the prevailing sterile buff calcareous clay found under all sites in the survey area. A lualde point and a Castroville point (Fig. $2, n$ ) were found in the third level of Unit $A$ between 40 and $60 \mathrm{~cm}$, along with two steeply-flaked thick unifaces. Unit $H$ contained two triangular points, one of which falls in the Early Triangular classification. Two steeply flaked heavy unifaces, deer bones and bone fragments were also found and a side-notched point came from surface contents (Fig. 2,0).

\section{KE 64}

This site is located along a ranch road about $600 \mathrm{~m}$ north of the $C$. A. Bergman home. Elevation in this area is approximately 1560'. It is approximately $100 \mathrm{~m}$ in diameter, with $1 \mathrm{ithic}$ debris scattered over the entire site area. A dense stand of cedar and scrub oak dominate the vegetation on the site.

The site was originally discovered by SCS archaeologist, James Warren, during a visit to the Upper Cibolo Creek Watershed. A subsequent intensive examination by the survey team indicated the presence of widely dispersed debitage and a few burned rocks. Shovel tests indicate that there are no buried deposits.

Diagnostic artifacts collected from the site surface included two Angostura basal fragments, a Pedernales fragment and three stemmed dart point fragments (not assignable to any presently defined type). The site has reportedly seen heavy collecting in the past.

\section{$41 K E 65$}

The site is located between $1540^{\prime}$ and $1560^{\prime} 300$ m northwest of $41 \mathrm{KE} 64$ and $400 \mathrm{~m}$ south of the confluence of an intermittent creek with Cibolo Creek. It lies in a circular clearing about $30 \mathrm{~m}$ in diameter, and consists of a thin scatter of 1 ithic debris and scattered burned rock. The survey team learned that considerable collecting had been done at the site in the past. An intensive surface search yielded an EnsorFrio point, an arrow point fragment and a concave-edged uniface. 
Shovel tests were dug to 1 imestone bedrock at $22 \mathrm{~cm}$; no subsurface cultural remains were observed.

\section{CONCLUSIONS AND RECOMMENDATIONS}

During the intensive survey conducted in the area of Floodwater Retarding Structure No. 1, Upper Cibolo Creek Watershed, 19 previously documented sites were re-examined and six new archaeological sites were discovered. Investigations at most of the sites included thorough surface observations and the excavation of shovel tests or test pits. Particular emphasis was placed on studies at sites 41 KE 33, 41 KE 49 and $41 \mathrm{KE}$ 63. As noted previously in the text, site $41 \mathrm{KE} 49$ was the scene of mapping, collecting and testing activities.

The archaeological resources of Floodwater Retarding Structure No. 1 span several thousand years. Evidence of Paleo-Indian occupation, probably of the 7000-6000 B.C. time level, was noted at sites 41 KE 49 , $41 \mathrm{KE} 52$ and $41 \mathrm{KE} 61$ where Plainview points were recovered; the Angostura type of probable terminal Paleo-Indian age was found at site $41 \mathrm{KE}$ 63. The Early and Middle Archaic (ca. 4500 to 550 B.C.; Prewitt 1974:Fig. 7) is particularly well represented in the study area, and we were especially impressed by the dominance of what appear to be Early Archaic and/or Pre-Archaic materials. At sites like 41 KE 33, 41 KE 49 and $41 \mathrm{KE} 50$ of the Pre-Archaic (cf. Sollberger and Hester 1972) and Early Archaic constitute the primary diagnostic remains.

Middle and Late Archaic artifacts are also found, but appear to represent less intensive occupations. Infrequent were the vestiges of Late Prehistoric habitations; site $41 \mathrm{KE} 63$ provided most of the surviving indications of this period, in the form of Perdiz arrow points and plainware ceramics.

In terms of site function, most of the localities studied by us appear to represent occupation or camping areas. A number of the sites,

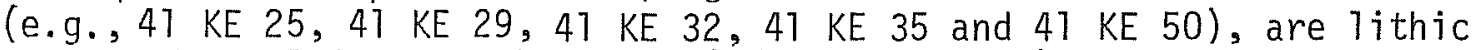
scatters resulting from brief periods of use, perhaps as temporary campsites or for special functions such as food-gathering or hunting. other sites, especially 41 KE 49 and 41 KE 63 saw more intensive occupation; these were probably preferred camping sites returned to by generations of hunters and gathers during years of subsistence explotation in the stream drainage. The only burned rock middens in the project area was noted at 41 KE 60. Similarly, the chipping stations or 1 ithic workshops was recorded at $41 \mathrm{KE} 62$; others may be situated at higher elevations in the uplands, where chert is more abundantly exposed.

Of importance in chronological studies in this area are our observations regarding the buff (or red) calcareous clay formation exposed at numerous (e.g., $41 \mathrm{KE} \mathrm{33,41} \mathrm{KE} \mathrm{35,41} \mathrm{KE} \mathrm{49,} 41 \mathrm{KE} \mathrm{63)} \mathrm{sites.} \mathrm{A11} \mathrm{of} \mathrm{the}$ human occupation of the area seems to $7 i e$ just above (or just within the top part of) this stratigraphic unit. For example, at site $41 \mathrm{KE} 49$, 
artifacts typical of the Pre-Archaic (ca.5500 B.C.; Prewitt 1974:Fig. 7) lie within the top few centimeters of this clay formation.

Most of the sites examined during the intensive survey require no further archaeological investigation in terms of the proposed modifications. These sites include: 41 KE $25,26,27,29,30,31,32,33,34,35,36$, $43,48,50,51,52,53,61,62,64$ and 65 . Site 41 KE 33 produced an extensive surface collection, yet eight shovel tests made at the site fajled to locate any areas with intact buried deposits. A careful study of the terrain suggests that the site was exposed by a grader or earthmover that scooped up fill for an erosion control dike immediately south of the site. The run-off from the field is deflected by this dike, forming a gully that has cut into the underlying buff calcareous clay formation. As this diversionary flow has proceeded west into Cibolo Creek, it has cut through to the basal 1 imestone on the west edge of the field. The combination of grading and continual erosion has completely deflated the site, leaving a 17 cultural remains exposed on a common surface. We therefore recommend no further studies at this site.

Site $4 T$ KE 60 is a burned rock midden lying well within the project area. However, it has been badly vandalized by relic-collectors and much of its archaeological potential has been destroyed. If it is determined that the project will even further damage this resource, we suggest that these modifications be preceded by a testing program so that the remaining deposits can be evaluated.

Site $41 \mathrm{KE} 37$ is the Agold family burial plot and is of no historical importance. If it is decided to modify this area, necessitating grave removal, the appropriate officials can contact Mrs. Hilda Agold (Boerne, Texas) for further information on this sma 11 cemetery. None of the other historic sites visited by the field team are felt to be of significance.

There are two archaeological sites within the boundaries of Floodwater Retarding Structure No. 1 that we believe are of such significance as to warrant their nomination to the National Register of Historic Places. These are sites 41 KE 49 and 41 KE 63. 41 KE 49 was extensively investigated by the intensive survey crew. It proved to be a site with burled deposits, intact features (such as hearths) and with cultural material dating from the Archaic and Pre-Archaic eras. Of special significance is the occurrence of considerable occupational remains from the Pre-Archaic transition. Further investigations at this site would undoubtedly provide much new information on this poorly known phenomenon.

Site 47 KE 63 is potentialiy a very valuable site and has already yielded to collectors and abundance artifacts ranging in age from late Paleo-Indian to Late Prehistoric times. Also of significance is the fact that bone is preserved in the site deposits, the only known site in the survey area with faunal preservation. The intensive survey team could devote only a relatively few hours to a study of this site; we do not yet know the areal extent of the site, but the deposits have proved 
to be deep.

Both $41 \mathrm{KE} 49$ and 41 KE 63 Tie on the edge of the proposed detention pool for Floodwater Retarding Structure No. 1. Neither will be directly affected by construction activities, although should large scale vegetation clearance take place (as it does on many similar scS projects), then the area of both sites should be avoided. Both sites will suffer occasional inundation as a result of the construction of the project. The SCS field office at San Marcos, Texas, has prepared an estimate of inundation frequency for the $41 \mathrm{KE} 49$ locality, and these data are presented in Table 1. In short, it would appear that this site, and portions of $41 \mathrm{KE} 63$ at similar elevations, will be inundated for relatively brief periods at frequencies ranging from two to 100 years. These data have been assessed in terms of a recent paper by $E$. G. Garrison (1975). Garrison's study deals with the probable effects of inundation on archaeological sites, particularly those affected by long-term submergence in large reservoirs and lakes. However, we still do not know what dangers are posed to sites by short-term flooding and accompanying factors such as backwater wave action and erosion. of course, Garrison's study is a preliminary one, and archaeologists, hydrologists and others who examine the paper are certain to have varying opinions until a time that more data become available. We suggest, however, that the SCS look into the possibility of insuring the protection of sites $41 \mathrm{KE} 49$ and $41 \mathrm{KE} 63$ by the installation of dikes or water diversion structures (cofferdams or breakwaters), or by covering portions of the sites with riprap; the latter would be most effective in those areas of the sites that might be subjected to backwater wave action.

We have one final concern, one that was briefly alluded to above. During the construction of some SCS floodwater retarding structures, we have observed that the basin and drainage areas within the structure are subjected to vegetation clearance. That is, bulldozers and similar heavy equipment clear and remove large trees, underbrush, etc., from the locality. This process is particularly destructive to shallow and surface archaeological sites, and from our observations, could even cause some damage to those sites with relatively thick deposits. Many of the sites in Floodwater Retarding Structure No. 1 constitute fragile archaeological phenomena. In our evaluation, most are not of National Register quality, but they nonetheless constitute important cultural resources. They should not be destroyed simply because an archaeological team has visited them on a couple of occasions. We would urge the SCS to flag the sites and to attempt to avoid as many of them as possible during any land clearing. 
TABLE T

POSTULATED FUTURE INUNDATIONS,

SITE 41 KE 49

\begin{tabular}{|c|c|c|c|c|c|c|c|c|}
\hline \multirow[b]{2}{*}{$\begin{array}{r}\text { Frequency } \\
\text { in years }\end{array}$} & \multirow[b]{2}{*}{$\begin{array}{c}\text { Elev. } \\
\text { Ft. }\end{array}$} & \multirow[b]{2}{*}{$\begin{array}{c}\text { Storage } \\
\text { Ac. Ft. }\end{array}$} & \multicolumn{2}{|c|}{41 KE 49: Unit Q } & \multicolumn{2}{|c|}{41 KE 49: Unit E } & \multicolumn{2}{|c|}{$4 T$ KE 49: Unit $R$} \\
\hline & & & $\begin{array}{c}\text { Elev. } \\
7531.7 \\
\text { Depth (Ft.) }\end{array}$ & $\begin{array}{l}\text { Ac. Ft. } \\
7600 \\
\text { Time (Hrs.) }\end{array}$ & $\begin{array}{c}\text { Elev. } \\
1525.2 \\
\text { Depth (Ft.) }\end{array}$ & $\begin{array}{c}\text { Ac. Ft. } \\
5800 \\
\text { Time (Hrs.) }\end{array}$ & $\begin{array}{c}\text { Elev. } \\
1524.4 \\
\text { Depth (Ft.) }\end{array}$ & $\begin{array}{c}\text { Ac. Ft. } \\
5600 \\
\text { Time (Hrs.) }\end{array}$ \\
\hline 2 & 1522.5 & 5160 & - & - & - & - & - & - \\
\hline 5 & 1526.2 & 6055 & - & - & 1.0 & 8 & 1.8 & 14 \\
\hline 10 & 1529.0 & 6795 & - & - & 3.8 & 30 & 4.6 & 36 \\
\hline 25 & 1531.9 & 7636 & .2 & 1 & 6.7 & 56 & 7.5 & 62 \\
\hline 50 & 1534.7 & 8368 & 2.4 & 23 & 8.9 & 78 & 9.7 & 84 \\
\hline 100 & 1536.4 & 9124 & 4.7 & 46 & 11.2 & 101 & 12.0 & 107 \\
\hline
\end{tabular}

The above table shows the time in hours necessary to draw the water down below the elevation of archaeological site $41 \mathrm{KE}$ 49. It also shows to what depth the different frequency rains will cover three parts of the site. For example, the 25 year frequency storm will cover the Unit 0 area with 2 feet of water, the Unit $E$ area, 6.7 feet, and the Unit $R$ area, 7.5 feet. Data assembled by the San Marcos Field Office, U.S.D.A. Soil Conservation Service. 


\section{BIBL IOGRAPHY}

Allen, D. C. and E. P. Cheatum

1961 Ecological Implications of Fresh-Water and Land Gastropods in Texas Archeological sites. Bulletin of the Texas Archeological Society 31 (for 1960):291-316.

Bass, F. A., Jr. and T. R. Hester

1975 An Archaeological Survey of the Upper Cibolo Creek watershed, Central Texas. Center for Archaeological Research, The University of Texas at San Antonio, Archaeological Survey Repart 8.

Garrison, E. G.

1975 A Qual itative Model for Inundation Studies in ArchaeoTogical Research and Resource Conservation: An Example for Arkansas. Plains Anthropologist 20(70):279-296.

Hester, T. R.

1971 Archaeological Investigations at the La Jita, Uvalde County, Texas. Bulletin of the Texas Archeological Society 42:51-148.

Hester, T. R., R. F. Heizer, and J. A. Graham

1975 Field Methods in Archaeology.6th Edition. Mayfield Publishing Company, Pa 1o Aito.

Hester, T. R. and H. Kohnitz, Jr.

1975 Chronological Placement of "Guadalupe" Tools. La Tierra 2(2).

Prewitt, E. R.

1974 Archeological Investigations at the Loeve-Fox Site, Williamson County, Texas. Texas Archeological Survey, Research Repart 49.

Sollberger, J. B. and T. R. Hester

1972 The Strohacker Site: A Review of Pre-Archaic Manifestations in Texas. Plains Anthropologist 17(58):326-344.

Sorrow, W. M., H. J. Shafer, and R. E. Ross

1967 Excavations at Stillhouse Hollow Reservoir. Papers, Texas Archeological Salvage Project 11. 
(flotation was also used; see below). As burned rocks were encountered, they were left in place until it could be determined if they were part of a buried feature, such as a hearth. Efforts were made to plot artifacts in situ (see Fig. $3, b$ ).

The test excavations produced the following characteristic profile: Surface to 15-20 cm was a dark brown humus-stained clayey soil disturbed by generations of plowing; $15-20 \mathrm{~cm}$ to $35-40 \mathrm{~cm}$ was a fairly homogenous brown to black clay soil; $35-40 \mathrm{~cm}$ to $80 \mathrm{~cm}$ was an apparently homogenous yel low to reddish-tinted buff compact calcareous clay. Limestone was encountered in several deep tests between 50 and $80 \mathrm{~cm}$. No artifacts were found more than five $\mathrm{cm}$ within the buff clay zone. As the earliest points found were of Pre-Archaic age, it is assumed that the buff clay was laid down prior to 6000 B.C. (Sorrow, Shafer and Ross 1967:142).

The investigations at 41 KE 49 a variety of 1 ithic materials (projectile points, bifacial and unifacial tools, preforms, cores, debitage), scattered burned rock, and in one area, a hearth with charcoal and an associated dart point. Materials excavated at the site have not been fully analyzed at the time of this writing. The materials, notes, analytical records and other data are on file at the Center for Archaeological Research, and will be the subject of detailed analysis in the future. In order to provide some comparative data for our colleagues who might be interested in the site collections, we have illustrated many of the diagnostic projectile points in Figs. 5-7; selected bifacial and unifacial tools are shown in Fig. 8. Identifiable projectile points found in the test excavations include Almagre, Bulverde, Gower, Lange, Langtry, La Jita, Marcos, Nolan, Uvalde and Wells. Also recovered were several specimens of the Early Corner-Notched and Early Triangular forms (Hester 1971), two lanceolate points and a series of five weak-shouldered, convex base dart points. No stratigraphic separation could be noted among the projectile point types in this assemblage, although comparisons with other published data from central and south central Texas indicate that Pre-Archaic, Early Archaic and Middle Archaic forms are represented.

Two units, $M$ and $N$, contained the only intact hearth area (at a depth of $35 \mathrm{~cm}$ ) and a good charcoal sample was obtained from it. A stemmed dart point identified as the La Jita type (Hester 1971:74) was found in apparent association with the hearth. The charcoal sample from the hearth was submitted to the Radiocarbon Laboratory of The University of Texas at Austin. Subsequent analysis produced a radiocarbon date of A.D. 830 (1120 \pm 60 B.P.; TX-2309). Given the stratigraphic position of the La Jita type as noted by Hester (1971), we believe this date to be much too late, perhaps attributable to either some disturbance not noted in the course of excavation or to some form of contamination.

Units $E, F, G, H, I, J, M$ and $N$ served to establish the south and west limits of the site. Units $M$ and $N$ push the north and east boundaries of the site farther out and more excavation would be necessary to firmly establish those limits of the site area. Units $0, P$ and $Q$ were placed in the southwest corner of the field and findings there indicate 


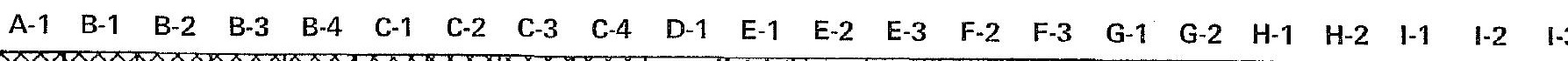

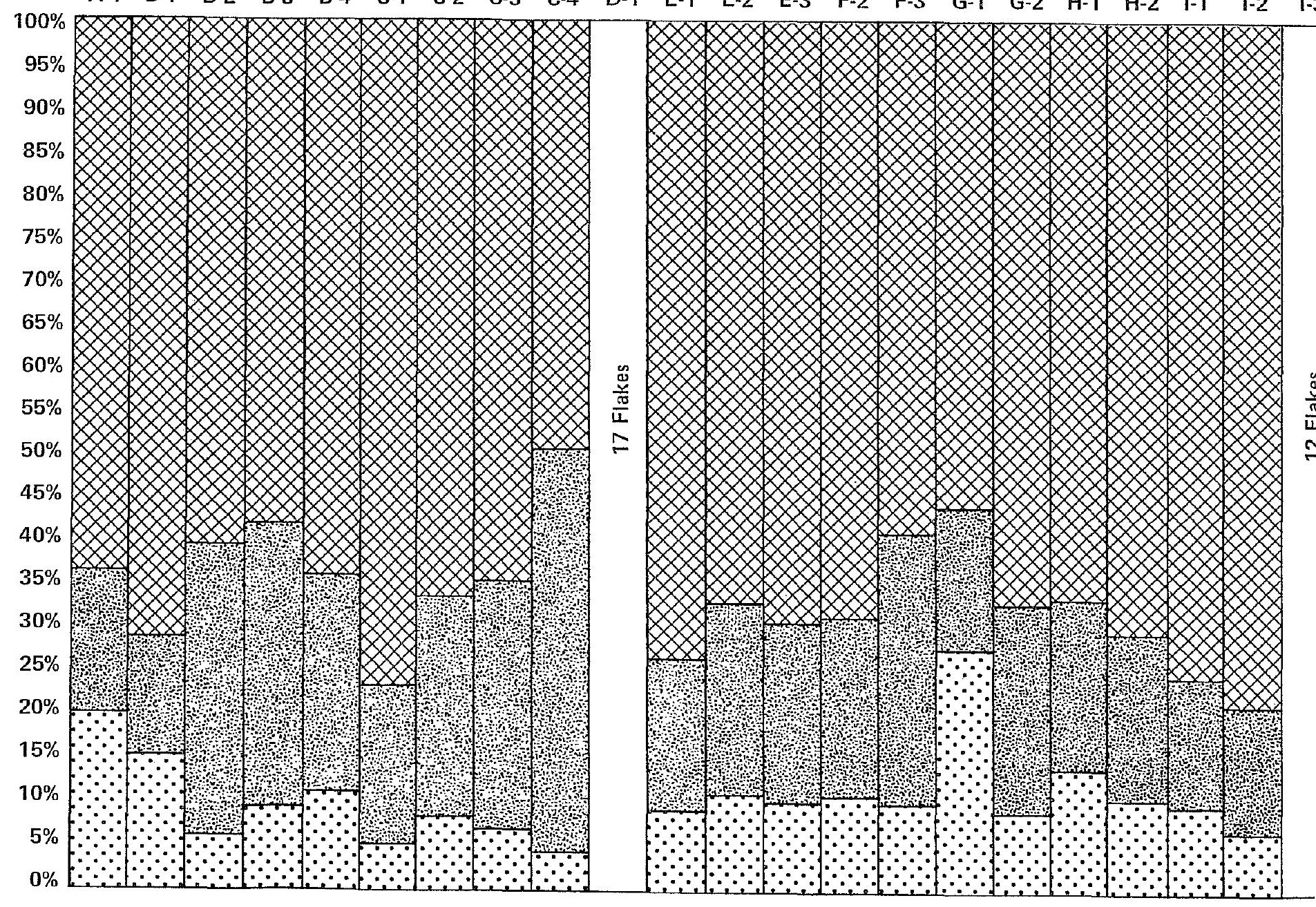

INTERIOR

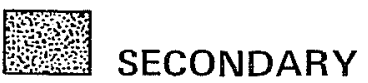

$\because \because$ PRIMARY

Figure 11. Flake Debris at 41 KE 49. Frequencies of flake cat are provided for primary, secondary, and interior flakes. 
